\title{
Commercial Real Estate Return Performance: A Cross-Country Analysis
}

\author{
by \\ David C. Ling and Andy Naranjo* \\ *Department of Finance, Insurance, and Real Estate \\ Warrington College of Business \\ University of Florida \\ Gainesville, FL 32611-7168 \\ Phone: (352) 392-0153 \\ Fax: (352) 392-0301
}

March 2000

Latest Revision: December 2000

We thank Piet Eichholtz, Pat Hendershott, Charles Ward, two anonymous referees, and participants at the Maastricht-Cambridge Property Investment Symposium for valuable comments and suggestions. We also thank Elvan Aktas for valuable research assistance and Piet Eichholtz and Han Op 't Veld of Global Property Research for assistance with the data. Additionally, we thank the Real Estate Research Institute for providing funding support for this project. 


\title{
Commercial Real Estate Return Performance: A Cross-Country Analysis
}

\author{
Abstract \\ This paper investigates the return performance of publicly traded real estate \\ companies. The analysis spans the 1984 to 1999 time period and includes return data on \\ over 600 companies in 28 countries. The return data reveal a substantial amount of \\ variation in mean real estate returns and standard deviations across countries. Moreover, \\ standard Treynor ratios, which scale country excess returns by the estimated $\beta$ eta on the \\ world wealth portfolio, also reveal substantial variation across countries in excess real \\ estate returns per unit of systematic risk. However, when we estimate Jensen’s alphas \\ using both single and multifactor specifications, we detect little evidence of abnormal, \\ risk-adjusted returns at the country level. We do, however, find evidence of a strong \\ world-wide factor in international real estate returns. Furthermore, even after controlling \\ for the effects of world-wide systematic risk, an orthogonalized country-specific factor is \\ highly significant. This suggests that real estate securities may provide international \\ diversification opportunities.
}




\section{Commercial Real Estate Return Performance: A Cross-Country Analysis}

\section{Introduction}

A global real estate securities market has slowly developed over the last two decades. At year-end 1999, the market value of publicly traded real estate companies was approaching \$400 billion. This public market provides a vehicle for investors to construct international commercial real estate portfolios without the burden of acquiring, managing, and disposing of direct property investments in far-away countries with unfamiliar legal, political, and market structures. ${ }^{1}$ However, to sustain and increase the flow of investment capital into the international real estate securities market, performance benchmarks and relative performance measurement are vital. This paper investigates the return performance of publicly traded real estate companies. The analysis spans the 1984 to 1999 time period and includes return data on over 600 companies in 28 countries.

At the simplest level, performance analysis consists of comparing historical returns and their variances. However, a key problem with this simple unconditional approach is that it does not explicitly consider the risks associated with the returns. In order to obtain more accurate risk-return characteristics, and to examine why a specific performance level occurred, more precise estimates of risk are needed. To date, the most widely used approach to risk adjustment has been the use of single- $\beta$ eta models such as the capital asset pricing model (CAPM). ${ }^{2}$

Although the single-ßeta approach is a positive first step toward controlling for systematic sources of return variation when assessing return performance, there is a growing consensus that single- $\beta$ eta models provide an inadequate description of security pricing. For

\footnotetext{
${ }^{1}$ See Eichholtz and Koedijk (1996) for a detailed discussion of the evolution and importance of international real estate securities markets.

2 See, for example, Glascock (1991), Glascock and Hughes (1995), Gyourko and Kiem (1992), Hartzell and Mengden (1987), Kuhle, Walther, and Wurtzeback, (1987), and McIntosh, Liang, and Tompkins (1991).
} 
example, several studies have uncovered multiple sources of systematic risk that are priced in U.S. commercial real estate markets (e.g., Chan, Hendershott, and Sanders, 1990, Ling and Naranjo, 1996, 1999, Ling, Naranjo, and Ryngaert, 2000, and Karolyi and Sanders, 1999). ${ }^{3}$ In an international context, several studies have found that continental and country specific factors, such as exchange rate risk, are additional sources of systematic risk (e.g., Eichholtz, et al., 1998, and Liu and Mei, 1996). Therefore, to appropriately measure both domestic and international real estate return performance, it is necessary to adequately control for country specific sources of systematic risk.

To form a base-line, we first examine the ex post return performance of each country’s real estate securities using a single-ßeta asset pricing model. Our proxy for the world wealth portfolio (i.e., systematic risk) is the total return on a broad-based index of international stocks. The estimated (Jensen’s) alphas from these regressions provide direct evidence of abnormal riskadjusted return performance. In addition, the estimated $\beta$ eta coefficients and coefficients of determination provide evidence on the extent to which country specific real estate returns respond to a global market risk factor. If returns on real estate securities in country $i$ are heavily influenced by a world-wide risk factor, this may suggest that investors already diversified internationally with stocks will gain little additional diversification benefits by investing in the real estate securities of country $i$.

In a second specification of our asset pricing model, we add a country specific factor to the ex post real estate return regressions. This additional variable is designed to proxy for the effects of systematic risk factors in each country that are independent of world-wide systematic risk. More specifically, this risk factor is the change in each country's stock market index that is 
orthogonal to movements in the world wealth portfolio. Once again, Jensen's alphas from the estimation of these two-factor models are examined for evidence of abnormal return performance by country.

Although our country-wide regressions provide a clear indication of the absolute and relative performance of each country's value-weighted real estate index, this level of aggregation may mask significant within-country variation in performance across property companies. To address this issue, we separately calculate the mean return and estimate our two-factor model for each of the companies that comprise the GPR database.

Our results can be summarized as follows. The data reveal a substantial amount of variation in mean real estate returns and standard deviations across countries. Moreover, standard Treynor ratios also reveal substantial variation across countries in excess real estate returns per unit of systematic risk. However, when we estimate Jensen’s alphas using single and multifactor specifications, we detect little evidence of abnormal returns at the country level. Similar to Case, Goetzman, and Rouwenhorst (1999), we find evidence of a strong world-wide factor in international real estate returns. However, even after controlling for the effects of world-wide systematic risk, our orthogonalized country-specific factor is significant in $91 \%$ of the country regressions. This suggests that real estate securities may provide international diversification opportunities.

The disaggregated results reveal significant variation in raw firm returns both across and within countries. This suggests significant firm specific risk exists in international real estate securities markets, even after controlling for world and country specific effects. Thus, diversification benefits may be available to international investors from investing in a limited

\footnotetext{
${ }^{3}$ In terms of other capital markets, several researchers have also shown that there are multiple risk factors in equity and bond returns. See, for example, Chen, Roll and Ross (1986), Ferson and Harvey (1991), and Fama and French (1993).
} 
number of countries. This may reduce the cost of constructing diversified international portfolios to the extent that there are up-front fixed costs associated with analyzing the legal, political, and market risks of individual countries. However, although the disaggregated total return data reveal significant variation across companies within countries, only a handful of companies produced statistically significant abnormal returns (alphas).

We perform several tests to examine the robustness of our results with respect to estimation methodology and to the asset pricing restrictions imposed. First, to avoid generated regressors and associated problems, we re-estimate our two-factor models using simultaneous equation estimation procedures. Second, we also re-estimate both the single- and two-factor models after imposing appropriate asset pricing restrictions. These conditional Jensen’s alphas are then compared to our earlier unconditional estimates. In both cases, we find that our excess performance results are virtually unchanged.

In Section 2 we present the conceptual framework for our study and describe the regression models used to analyze cross-country performance. Section 3 describes the data and presents various descriptive statistics such as unconditional mean returns and standard deviations. Section 4 contains the empirical regression results using country-level data, while our disaggregated (firm-level) results are presented in section 5. Several robustness checks are performed and discussed in section 6, and the last section offers some concluding comments.

\section{Research Methodology}

A widely used framework for estimating excess (risk-adjusted) returns is Jensen’s CAPM approach. To implement this approach in our international context, we estimate the following OLS regression:

$$
R_{i t}-R_{f t}=\alpha_{i}+\beta_{i w}\left[R_{w t}-R_{f t}\right]+e_{i t}
$$


where:

$R_{i t} \quad=$ the U.S. dollar-weighted return on country i's real estate index in time period $t$,

$R_{f t} \quad=$ the U.S. risk free rate in time period $t$,

$\alpha_{i} \quad=$ a constant,

$\beta_{\text {iw }} \quad=$ the return sensitivity (exposure) of country i's real estate returns to returns on the world wealth portfolio,

$R_{w t}=$ the U.S. dollar-weighted total return on the world wealth portfolio in time period $t$,

$R_{w t^{-}} R_{f t}=$ the expected risk premium associated with an investment in the world wealth portfolio, $\mathrm{e}_{i t} \quad=$ an error term.

Each country’s alpha, $\alpha_{i}$, represents the constant periodic return the investor is able to earn above (or below, if negative) the return on an unmanaged portfolio of international stocks (i.e., a buy-hold strategy) having identical market (systematic) risk. Thus, if the estimated alpha value from this ex post return regression is positive and statistically significant, the country level index of real estate returns is judged to have outperformed a buy-hold international strategy. Conversely, if the estimated alpha coefficient is negative and statistically significant, the real estate index has underperformed a passive buy-hold international strategy.

Jensen's model assumes there is but one source of systematic risk in the economy-i.e., exposure to fluctuations in the value of the world wealth portfolio. However, as noted earlier, several recent studies have documented the existence of multiple systematic risk factors in both domestic and international stock, bond, and commercial real estate markets. Thus, Jensen's and other single-factor performance evaluation models may be mis-specified due to the existence of an omitted variable(s). The potential ramification of this mis-specification is that apparent excess return performance may simply reflect the risk premium(s) investors have earned for exposure to additional sources of systematic risk. However, because these additional risk factors are omitted from single-factor models, the return compensation attributable to these risk exposures may be erroneously picked up in the intercept and error terms, leading to incorrect return performance inferences. 
In studies of U.S. real estate markets, the most common approach to specifying multifactor models of asset prices is to use macroeconomic factors and/or other variables that have been shown in prior studies to carry ex ante risk premiums. ${ }^{4}$ The use of prespecified factors is not possible in the current study for several reasons. Most importantly, identifying a set of consistently "priced factors" in each country is problematic due to the length and breadth of the available real estate data for each country. Moreover, many of the "usual suspects” (i.e., changes in interest rates, term structure slopes, industrial production, national consumption, etc.) are not available in a consistently measured and timely fashion across the countries in our sample. $^{5}$

To circumvent these international data limitations, we employ a two-factor variant of the model used by Liu, et al. (1990). This two-factor model serves as a general specification for other multifactor asset-pricing models through the use of two portmanteau variables that proxy for latent asset pricing risks including country-related macroeconomic state variables, predetermined factors, and institutional factors. The estimation of this model requires a two-step procedure. First, for each country in our sample, we estimate the following OLS regression:

$$
R_{i t}^{s}-R_{f t}=\alpha_{i}^{s}+\beta_{i w}^{s}\left[R_{w t}-R_{f t}\right]+e_{i t}^{s},
$$

where $R_{i t}^{S}$ is the U.S. dollar-weighted return on country i's stock index in time period $t$ and $e^{S}{ }_{i t}$ are the unexplained residuals (i.e., the orthogonal component). These residuals represent the portion of each country's stock returns not explained by movements in the world wealth portfolio. This unexplained variation serves as a portmanteau variable that proxies for latent country-related macroeconomic state variables and predetermined factors such as changes in interest rates and

\footnotetext{
${ }^{4}$ See, for example, Ling and Naranjo (1996, 1998).

${ }^{5}$ Historical bond data to measure the default premium, for instance, are unavailable across most of the countries in our sample.
} 
term structure slopes, growth rates in industrial production, per capita consumption, size related effects, and exchange rate risk. These residuals also capture the effects of the myriad institutional factors that can vary significantly across continents and countries and that standard asset pricing models generally ignore. ${ }^{6,7}$

To estimate a multifactor specification of the unconditional real estate asset-pricing model, we add this orthogonalized country-specific risk factor to the ex post real estate return regressions and estimate the following equation:

$$
R_{i t}-R_{f t}=\alpha_{i}+\beta_{i w}\left[R_{w t}-R_{f t}\right]+\beta_{i R} e_{i t}^{s}+u_{i t}
$$

As before, $\beta_{i w}$ is the estimated return sensitivity of country i's real estate return index to returns on the world wealth portfolio. $\beta_{i R}$ is the estimated exposure of country $i$ 's real estate return index to returns on the orthoganalized country specific risk factor. If $\beta_{i R}$ cannot be distinguished from zero, we conclude that the country specific risk factor does not increase the explanatory power of the model, once we have controlled for world-wide systematic risk. Once again, the estimated constants (Jensen’s alphas) from this two-factor model can be examined for evidence of superior risk-adjusted return performance.

Because return-influencing events in real estate markets are decidedly local in nature, we anticipate that our estimates of $\beta_{i R}$ will be statistically significant. However, with the gradual emergence of international real estate capital flows during our study period, real estate markets

\footnotetext{
${ }^{6}$ Institutional factors can take many forms and shapes. Geurts and Jaffe (1996) list and discuss 16 variables that can be linked with the economic consequences of the institutional framework.

${ }^{7}$ A potential alternative specification is to use a continental factor in place of the country or world factor. However, at a theoretical level, there is no clear justification for a continental factor. Moreover, an additional concern is that the use of a continental factor imposes the assumption that the countries within each continent are integrated, whereas the two factors that we use allow for the returns to fluctuate with respect to domestic influences (potentially segmented events) and world influences (potentially integrated events) (see Ling and Naranjo, 1999). Lastly, to the extent the continental effects are not correlated with the world influences, they are subsumed in the country factors that we employ.
} 
have generally experienced increased openness and competition. This suggests that the relative influence of the world index on real estate returns may have increased over the study period.

\section{Data}

The international real estate securities data used in this study are obtained from the Global Real Estate Securities Database of Global Property Research (GPR), a Netherlands-based firm. This database contains prices, market capitalization, dividends, and company characteristics of real estate companies listed on the stock exchanges of more than 30 countries on a monthly basis since 1984 . This unique database contains the history of some 600 real estate companies_-both currently listed companies and those that have been delisted. The GPR index is constructed to be representative of the movements in the worldwide real estate securities market. In December 1999, the aggregate GPR index contained return information on 434 companies in 30 countries. The market value of these securities was $\$ 362.7$ billion. $^{8}$

Most of the GPR times-series began in January 1984, and we currently have data through December 1999. The GPR database is consistent across countries with respect to the inclusion criteria of companies, the treatment of initial public offerings, and the distinction between property development and property investment companies. The GPR country indices are available on both a market value-weighted and equally-weighted basis, although we primarily use the market-weighted indices in this study. ${ }^{9}$

\footnotetext{
${ }^{8}$ We have chosen to include the broadest possible set of countries (all 30 countries when possible). It is important to note that the retention of specific countries does not have a consequential effect on our overall results since our analysis is not aggregated across countries.

9 The GPR Index includes companies for which the market capitalization is over 50 million in U.S. dollars for two consecutive months. Companies are included for which at least $75 \%$ of revenues is derived from investment activities or a combination of investment and development activities. The Index includes office, residential, retail, industrial, health care, hotel, and diversified real estate companies. If a company derives more than $75 \%$ of its revenue from one country, not being the country of its primary listing, the company is placed in the index of the country in which the assets are located. Dividends are included in the index at the ex-dividend date and are assumed to be reinvested in the index. See Eichholtz et al. (1998) for more details.
} 
The country-level and world capital market equity indices (i.e., country and world wealth portfolio proxies) are compiled by Morgan Stanley Capital International (MSCI) and are obtained from Datastream. ${ }^{10}$ The MSCI indices are the most widely used country and world indices by international money managers for asset allocation decisions and performance measurement. They are also widely used by academic researchers because of their consistency, extensive market coverage, and historical availability dating back to 1970 . The MSCI total return indices (with dividend reinvestment) are value-weighted and composed of stocks that broadly represent each market. ${ }^{11}$ Non-nationals can also readily purchase the stocks in these indices. All the returns are calculated in excess of the U.S. Treasury bill closest to 30 days to maturity on the last trading day of the month. These interest rate data are from Ibbotson and Associates.

\subsection{Advantages and Limitations of the Data}

Although the GPR database is constructed to representative of the universe of publicly traded real estate companies, it is important to note that returns on these securities may not accurately reflect returns in private real estate markets, which is where the majority of commercial real estate in most countries is valued and exchanged. Eichholtz and Hartzell (1996), Giliberto and Mengden (1996), and others argue that property share prices are likely to be more volatile than the underlying real estate assets for several reasons. First, because these public real estate firms are operating companies, their share prices are sensitive to the market's

\footnotetext{
${ }^{10}$ Ideally, the world wealth portfolio should include the whole range of instruments: real estate, stocks, bonds, commodities, and so on. Unfortunately, these data are not generally available on a global basis and the market size of them is not known precisely. However, given common fluctuations in the factors that comprise the world wealth portfolio, it is likely that our market portfolio proxy is highly correlated with the "true" world portfolio.

Furthermore, to the extent that there are measurement errors, these are likely to be mitigated with the two-factor specification that we employ.

${ }^{11}$ For example, there is a 99\% percent correlation between the MSCI U.S. return and the value-weighted return calculated by the Center for Research in Security Prices at the University of Chicago.
} 
changing assessment of the quality and vision of the management team. Second, because the securities are publicly traded, they are exposed to the arbitrage forces of the public market. Nevertheless, there is an obvious link between the performance of real estate in the public and private markets.

Several authors who have investigated international real estate portfolio issues have used time series of rents and capitalization rates, instead of property share return data, in their research (e.g., Goetzman and Wachter, 1996, and Case, Goetzman, and Wachter, 1999). The advantage of such an approach is that the database may contain information on a larger sample of the commercial real estate stock in a given market or country. The disadvantages of this approach reflect the problems of infrequent trading and the lack of a central marketplace for privately held and traded assets. Moreover, rents and capitalization rates in different countries are hard to compare, given the international variation in rental contracts. ${ }^{12}$ Real estate stock indices have the advantage that they are publicly traded, transaction-based, transparent, and reported on a frequent basis (Lizieri, et al., 1998). For these reasons we limit our analysis to publicly traded property shares. ${ }^{13}$

\subsection{Descriptive Statistics}

Table 1 provides descriptive statistics for the full sample period from 1984-1999. On average, the aggregate GPR index was comprised of 277 firms over the 192 sample months. However, many of the country-level returns must be interpreted with caution due to the small number of companies that comprise the index in some countries. In fact, the return indices in 12 of the 20 countries in the 1984 to 1999 sample are calculated with an average number of

\footnotetext{
${ }^{12}$ See Corgel, Jaffe, and Lie (1992) and Geurts and Jaffe (1996) for an expanded discussion of these international differences.

13 Additional studies that investigate international real estate securities include Asabere, Kleiman, and McGowan (1991), Barkham and Geltner (1995), and Liu, Hartzell, and Hoesli (1997). Because our focus is on the
} 
companies less than 10 . The last two columns in Table 1 reveal that six countries dominate the aggregate GPR index. On average, Japan accounted for $\$ 34.4$ billion, or 18.9 percent, of the market value of the aggregate index. Japan's average contribution to the aggregate index was closely followed by the U.S. with an average market capitalization of \$33.5 billion. Hong Kong (15.8\%), the United Kingdom (10.9\%), Germany (10.3\%), and France (7.0\%) followed in importance. The remaining countries each contributed less than 4 percent, on average, to the market value of the aggregate GPR index.

The first and second columns of Table 1 contain the annualized mean monthly return and standard deviation, converted into U.S. dollars. For example, the U.S. posted an average annual return of 10.9 percent over the 1984 to 1999 period with a standard deviation of 15.1 percent. On a market-weighted basis, GPR's collection of publicly traded real estate companies produced an 11.4 percent annual return with a standard deviation of 17.2 percent. There was, however, a great deal of variability around the 11.4 percent aggregate return. For example, Hong Kong and Singapore produced total returns in excess of 20 percent per year, while Canada severely underperformed with an annual return of -7.9 percent per year.

Based on univariate return statistics, international real estate securities underperformed relative to the world wealth portfolio (proxied by Morgan Stanley’s world index of international stocks) over the 1984 to 1999 period. The world wealth/stock portfolio produced both a higher mean annual return than real estate securities (15.9\% vs. $11.4 \%)$ and a lower standard deviation (14.4\% vs. 17.2\%). From the perspective of a U.S. based investor, the GPR index also underperformed relative to U.S. stock and bond markets on a raw return per unit of total risk basis. For example, large cap U.S. stocks provided an average annual return of 17.7 percent and a standard deviation of 14.8 percent (a return per unit of risk ratio of 1.19). This compares

performance of real estate securities, and not on the links between the securities and the underlying commercial real 
favorably with the return/risk ratio of 0.66 (11.4\%/17.2\%) produced by the value-weighted aggregate real estate securities index. With a return/risk ratio of 1.15 (11.2\%/9.8\%), the U.S. long-term government bond index also outperformed the aggregate GPR index. The aggregate return/risk performance of international real estate companies more closely approximated the returns on the U.S. small cap index $(13.1 \% / 17.8 \%=0.73)$.

The absolute and relative performance of international real estate securities varies significantly across our sub-periods. Although the aggregate GPR index produced a mean annual return of 11.4 percent over the full sample period, the average return during the 19841989 period was 26.4 percent (see Table 2). This exceeds the corresponding 22.5 percent average return on the world wealth portfolio. In addition, the aggregate GPR index significantly outperformed the three U.S. benchmarks on a return per unit of risk basis during 1984-1989.

The average market capitalization of Japanese real estate companies accounted for 37.4 percent of the aggregate index during the 1984 to 1989 period. This is especially significant because the Japanese securities produced an average annual return of 48.5 percent during this period. Hong Kong securities, which on average contributed 9.4 percent of the aggregate capitalization on the index during this period, produced an average return of 38.4 percent per year. Thus, nearly 50 percent of the market capitalization of the aggregate index was contributed by two countries that averaged better than 38 percent annual returns. However, these two Asian economies were not alone in producing large, and volatile, real estate returns. In fact, no country represented in the index generated an average return of less than 13 percent and most were significantly higher, albeit with, in most cases, significant volatility.

The boom in global real estate security prices came to an end during the 1990s. The total return to the aggregate GPR index averaged just 2.4 percent per year (see Table 3). Aggregate 
return volatility, however, was only slightly lower (15.2\%) than during the booming 1980 s. The average annual return to the world wealth portfolio also declined significantly from 22.5 percent in 1984-1999 to 11.8 percent in the 1990 s. However, this 11.8 percent return exceeded by a factor of five the return on the aggregate GPR index. The poor performance of the GPR index is even more pronounced when compared to the average returns produced by U.S. large cap stocks (18.0\%) and small cap stocks (15.7\%) during the 1990s.

The average number of firms in the aggregate index increased significantly to an average of 340 in the 1990s. The corresponding average market capitalization was $\$ 240$ billion. The U.S. replaced Japan as the largest contributor of market capitalization to the aggregate indexaccounting for 20 percent, on average, of the aggregate index during this period. The U.S. was followed by Hong Kong (17.2\%), Japan (15.0\%), Germany (11.1\%), and the United Kingdom $(10.3 \%)$

\subsection{Treynor Ratios}

The means and standard deviations reported in the first two columns of Tables 1-3 clearly indicate that international real estate returns have been quite volatile. However, modern portfolio theory posits that only systematic risk, not total risk, is priced in competitive capital markets. Thus, from the perspective of an investor seeking to build a diversified portfolio of international real estate securities, a more appropriate measure of risk is the extent to which returns in a particular country are likely to co-vary with returns on the world wealth portfolio (WWP). To address this question, monthly returns in excess of the U.S. Treasury bill rate for each country were regressed on the world wealth portfolio’s excess return (see equation (1)). The $\beta$ etas from these ex post regressions measure the degree of (world-wide) systematic risk in each country's real estate securities. The mean excess return in each country was then divided by the WWP $\beta$ eta to produce a standard Treynor ratio for each country, and for the aggregate 
GPR index, for the full sample and both sub-periods. ${ }^{14}$ The Treynor ratios, and the relative ranking of each country based on its Treynor ratio, are displayed in columns 3 and 4 of Tables 1-

3.

The Treynor ratio for the aggregate GPR index was 0.51 over the 1984 to 1999 period. The ratio ranged across countries from 2.0 to -1.31 . Two countries with large real estate securities markets, Germany and Hong Kong, performed very well, ranking second and fourth, respectively. The U.S. ratio of 0.73 put it squarely in the middle of the 20 countries for which we had adequate data to calculate returns for the 1984 to 1999 time period.

The Treynor ratio for the aggregate GPR index was 1.66 in the 1984-1989 period, which is reflective of the general real estate boom that affected most, but not all, real estate markets during this period. With a ratio of 1.00, the U.S. ranked 17 out of 20 countries. This poor relative performance was caused by the significant downturn that hit most U.S. real estate markets in the mid-to-late 1980s. In sharp contrast to the 1980s, the Treynor ratio for the aggregate GPR index was -0.24 percent in the 1990 s. This reflects the severe real estate recession that began in the U.S. in the 1980s and finally swept across many international markets during the 1990s. Many U.S. commercial real estate markets began to recover in the early 1990s and most were booming by the late 1990s. Thus, the U.S. managed a Treynor ratio of 0.52 during the 1990s, which placed it eighth out of 28 countries.

\section{Regression Results}

\subsection{Single-Factor Model}

\footnotetext{
${ }^{14}$ Treynor ratios are discussed in Chapter 21 of Commercial Real Estate Finance and Investment, David Geltner and Norm Miller, Prentice Hall, forthcoming.
} 
The Treynor ratio permits us to rank the relative excess return performance of countries based on a measure systematic risk. However, it does not allow us to determine whether real estate securities provided investors with positive (or negative) risk-adjusted (i.e. abnormal) returns. To address this issue, we estimate both the single-factor and two-factor return regressions for our three sample periods. ${ }^{15}$ An estimated alpha significantly different from zero indicates abnormal return performance.

Table 4 displays the regression results obtained from using a single risk factor--the world stock portfolio--to measure ex post return performance. The first panel in Table 4 presents results from the full sample period. The second and third panels display results for our two subperiods. Coefficient estimates for $\alpha_{i}$ and $\beta_{i w}$, along with the adjusted $\mathrm{R}^{2}$, are reported in the first row for each country. T-statistics are in parentheses, with significance at the $10 \%$ level indicated by an asterisk (“*”).

When the aggregate value-weighted GPR monthly index is regressed on a constant and the world wealth portfolio, the estimated alpha for the full sample period is -0.321 per month, or 3.85 percent per year (see the last row of Table 4). However, because the t-statistic is -1.391 , we cannot reject the null hypothesis that the risk adjusted abnormal return on the aggregate GPR index is zero. Although the estimated alphas for numerous countries are large, the standard errors of the estimates preclude us from concluding the abnormal performance is statistically significantly different from zero. The only exception during 1984-1999 is Canada.

It is interesting to note that the $\beta$ eta with respect to the world wealth portfolio is 0.933 for the aggregate GPR index, strongly indicating that a value-weighted portfolio of publicly available international real estate securities was comparable in (systematic) risk to the world

\footnotetext{
${ }^{15}$ It is important to note that we include the single-factor results for comparison with the Treynor ratios that were calculated from the single-index model and for comparison purposes with earlier studies that employ single-factor models.
} 
wealth portfolio over the full sample period. Moreover, returns on the WWP explain 61 percent of the variation in aggregate GPR returns. The country specific ßetas are all positive and statistically significant and the adjusted $\mathrm{R}^{2}$ s range from 0.019 (Germany) to 0.338 (Japan). These results suggest that a world-wide systematic risk factor explains a significant proportion of the cross-section of international real estate returns.

The single-index results are similar for our two sub-periods with respect to the number of countries that produce statistically significant abnormal returns. During the 1984 to 1989 time period, only Sweden’s abnormal return of 1.608 per month (or $19.30 \%$ per year) is distinguishable from zero at the 10 percent level of significance. During the 1990 to 1999 period, Canada, Japan, the Netherlands, and Portugal produced negative excess returns (alphas) that are statistically significant.

The $\beta$ eta with respect to the WWP for the aggregate GPR index is 0.968 in the 19841989 period and 0.887 in the 1990s. These results, coupled with the $\beta$ eta of 0.933 for the full sample, strongly suggest that a value-weighted portfolio of publicly available international real estate securities has been comparable in systematic risk to the WWP. This, in turn, suggests that international stock investors who are seeking to diversify their portfolios by adding real estate securities may want to hold those securities in proportions different from their relative contributions to the aggregate GPR index.

\subsection{Two-Factor Model}

The results from estimating our two-factor model [equation (3)] are displayed in Table 5, with results for the 1984-1999 period contained in the first panel. Several results from this estimation are worth noting. First, the country alphas are little changed by the addition of the 
country specific risk factor. For example, the estimated alpha for the U.S. is now -0.083 per month, versus -0.075 in the single-factor model. A simple average of the 20 country alphas is now -0.097 , versus -0.074 in the single-factor model. Although the estimated alphas remain virtually unchanged, the alphas for Hong Kong (0.799) and the Netherlands (-0.944) are now statistically significant at the 10 percent level.

A comparison of the WWP $\beta$ etas in the single- and two-factor models reveals they are remarkably invariant with respect to the addition of the country specific factor during the 19841999 period. However, the addition of the country specific factor has a significant effect on the ability of the regression model to explain the cross-section of real estate returns in each country. In all but one of the 19 countries represented in our 1984-1999 sample, the estimated coefficient on the country-specific risk factor is positive and highly significant. For example, the estimated coefficient on the U.S. factor is equal to 0.609 with a t-statistic of 6.977. Relative to the singlefactor model, the inclusion of the U.S. risk factor increases the adjusted R-squared of the U.S. model from 0.308 to 0.448 . The increase in explanatory power from adding a country-specific factor is even more pronounced in many other countries. Overall, the (equally-weighted) average R-squared for our 19 country sample in the 1984-1999 period increases from 0.152 to 0.388 with the addition of the country specific factor.

Interestingly, the effect of adding a country specific risk factor on the estimated alpha is more pronounced in our two subperiods. For example, the estimated U.S. alpha during the 19841989 changes from -0.214 in the single-factor model to 0.210 in the two-factor model.

Moreover, the estimated U.S. WWP $\beta$ eta moves from -0.538 in the single-factor model to 0.648 in the two-factor model. The estimated alphas also vary considerably between the single- and two-factor models in the 1990-1999 period. These frequently large shifts in the slope of the estimated regression line from one subperiod to the next suggest the ex post return regressions 
may be mis-specified when the country specific factor is excluded. ${ }^{16}$ Moreover, the misspecification is more pronounced the shorter is the sample period. This result is intuitively appealing because it suggests the influence of international capital markets on within-country average real estate returns is more pronounced the longer is the sample period. However, these results should be interpreted with caution given that the estimated alphas, although frequently large in magnitude, are generally lacking in statistical significance in both the single-factor and two-factor models.

Despite the large (26.4\%) annual average returns earned by the aggregate GPR index in 1984-1999, only two countries had estimated alpha coefficients significantly greater than zero: Sweden in the single-factor model and Hong Kong in the two-factor model. During the 1990s, Canada, Japan, the Netherlands, and Portugal significantly underperformed on a risk-adjusted basis in both the single- and two-factor models. It also is worth noting that the aggregate GPR index produced statistically significant negative abnormal returns in the 1990s. The estimated alpha in the single-factor specification is -0.721 , or 8.65 percent annually (t-statistic $=2.976$ ).

Looking at the regression explanatory powers $\left(\mathrm{R}^{2} \mathrm{~s}\right)$, we find that they are positively correlated with each country's share in the world portfolio (0.48), and this result is robust over our sub-periods. Interestingly, although there is a positive relation between the regression explanatory powers for each country and the number of firms in the index, this relation varies substantially over our sub-periods ( 0.56 for the 1980 's and 0.10 for the 1990 's), suggesting that the increase in the number of firms in the 1990's added potentially more idiosyncratic noise. It is important to note that this result is particularly relevant for the U.S. and for some of the smaller countries with few firms. Finally, the distribution of beta coefficients with respect to

\footnotetext{
${ }^{16}$ As a further robustness check, we also tried various leads and lags of the two factors. The leads of lags of the two factors were not significant when the contemporaneous factors were included in the regressions.
} 
time and their relation to the regression $\mathrm{R}^{2 \text { s }} \mathrm{s}$ is marginally positive, indicating a slight increase in country real estate sensitivity to world market movements.

\section{Firm Level Performance by Country}

As discussed in the previous section, only a handful of country-level regressions produced statistically significant alphas, despite the significant variation in total returns across countries. However, aggregation to the country level may mask significant within-country variation in return performance across property companies. To examine this issue, we first calculate the mean return for each company in the GPR database. To be included in the company level sample, a total return for the firm must have been reported in at least 90 of the 120 months that comprise the 1990-1999 time period. As reported in Table 6, 202 companies in 14 countries satisfied our inclusion criterion.

For each of the 14 countries in this subsample, we report in Table 6 the average return for the firm with the highest, median, and lowest average total return, respectively, during the 1990s. For example, return data on 39 U.S. firms were available in at least 90 months during the 1990s. The mean company level returns ranged from a high of 33.6 percent per year to a low of -6.3 percent. The annualized mean return for the median U.S. firm was 12.2 percent. Numerous other countries also display substantial variation in average returns across firms. For example, the average 1990s firm level return in the U.K. ranged from 74.5 percent to -19.1 percent annually, with a median of 9.6 percent. Overall, the results in Table 6 strongly suggest that a great deal of company specific risk exists in international real estate securities. Moreover, these results suggest that strategic diversification both across and within countries may result in more risk reduction at the international portfolio level than would be accomplished with a strategy of holding a portfolio in each country that mimics a value-weighted real estate securities index. 
Although the disaggregated total return data reveal significant return variation across companies within countries, it does not necessarily follow that a significant number of firms earned positive or negative risk-adjusted returns. To examine ex post performance, we separately estimate our two-factor model [equation (2)] for each of the 202 companies in our firm-level sample. These results are reported in Table 7. The number of positive and negative firm level alphas in each country is based on statistically significant alphas (at the 10 percent level).

The lack of statistically significant alphas in Table 7 is noteworthy. Of the 202 firms in this subsample, only nine produced positive abnormal returns. Twenty-four companies produced negative abnormal returns. However, 17 of these are Japanese firms--a country that experienced a severe commercial real estate recession during the 1990s. Despite the exceedingly poor relative performance of U.S. real estate stocks in 1998 and 1999, none of the 39 U.S. companies produced negative returns on a risk-adjusted basis.

Despite the apparent lack of company level abnormal return performance in most countries, the results in Table 7 should be interpreted with caution for several reasons. First, it is well known that the noise embedded in firm level total return data makes it difficult to reject the null hypothesis of no abnormal return performance. Second, the results assume that the assumptions of our asset pricing model are valid. In particular, these results are predicated on the assumption that all systematic risk in each country is proxied by movements in our two risk factors. Finally, our estimations were performed without imposing standard asset pricing restrictions. This latter issue is addressed in the following section.

\section{Robustness Checks}


In estimating Jensen’s alphas with our two-factor model, we used a two-step regression procedure. A potential problem with this approach is that the second regression used to estimate Jensen's alphas contains a generated regressor (i.e., the orthogonal component) with a potential errors-in-variables problem. To assess the effects of this potential problem, for each country, we used non-linear simultaneous equation regression procedures to jointly estimate both equations associated with the two-step regression procedure (see Pagan 1984). We find that the results reported in Table 5 are virtually unchanged for each country.

An additional potential concern is that the models that we have estimated are unconstrained versions of the corresponding asset pricing models. In particular, we have not imposed the asset pricing restrictions implied by each of the models. For instance, in the twofactor model, we estimate:

$$
R_{i t}-R_{f t}=\alpha_{i}+\beta_{i w}\left[R_{w t}-R_{f t}\right]+\beta_{i R} e_{i t}^{s}+u_{i t}
$$

Equation (3) is the unconstrained version of the following two-factor asset pricing model,

$$
R_{i t}-R_{f t}=-\lambda_{0} \beta_{i w}+\lambda_{2} \beta_{i R}+\beta_{i w}\left[R_{w t}-R_{f t}\right]+\beta_{i R} e_{i t}^{s}+u_{i t}
$$

where $\lambda_{0}$ is the zero-beta excess rate of return (the return in excess of the risk-free rate) and $\lambda_{2}$ is the risk premia corresponding to the second factor. Note that the risk premia corresponding to the market factor falls out of the estimating equation (see Liu, et al., 1990, and Ling and Naranjo, 1996, 1999). The model corresponding to (4) is derived by substituting the expected returns asset pricing equation into the returns generating equation implied by the asset pricing model. From equations (3) and (4), we can see that the constraint in equation (4) is on the intercept (alpha) in equation (3): $\alpha_{i}=-\lambda_{0} \beta_{i w}+\lambda_{2} \beta_{i R}$.

In order to estimate the parameters in equation (4) for each country, it is necessary to simultaneously estimate pricing equations for at least as many portfolios (firms) as there are risk factors. In simultaneously estimating equation (4) within each country, we would ideally like to 
use portfolio level data to reduce the idiosyncratic noise associated with using firm level data. Unfortunately, with the exception of a couple of markets, we do not have a sufficient number of firms within each market to construct various real estate portfolios. We therefore are restricted to using the firm-level data to estimate equation (4). Moreover, for several of the countries, there were an insufficient number of firms to estimate equation (4). For the remaining countries, however, we again find that the excess performance results are very similar to those reported in Table 5. ${ }^{17}$

\section{Concluding Remarks}

The diversification potential associated with investing internationally has received increased attention in recent years from both academics and practitioners. However, the risks and uncertainties of direct real estate investments in foreign countries have generally outweighed the possible reductions in portfolio risk from international diversification.

Over the last two decades, a global real estate securities market has slowly developed. Compared to private markets, this growing public market provides a vehicle for investors to construct international commercial real estate portfolios without the significant burden of acquiring, managing, and disposing of direct property investments in far-away countries with unfamiliar legal, political, and market structures. However, little is currently known about the return performance and diversification potential of the international real estate securities market. This paper investigates the return performance of publicly traded real estate companies. The analysis spans the 1984 to 1999 time period and includes return data on over 600 companies in 28 countries.

\footnotetext{
${ }^{17}$ Over the 1990-1999 sample period, for instance, we could obtain estimates of equation (4) for Australia, Canada, France, Germany, Hong Kong, Japan, the Netherlands, Switzerland, U.K., and the U.S.
} 
Our results can be summarized as follows. The return data reveal a substantial amount of variation in mean real estate returns and standard deviations across countries. Moreover, standard Treynor ratios also reveal substantial variation across countries in excess real estate returns per unit of systematic risk. However, when we estimate Jensen's alphas using single and multifactor specifications, we detect little evidence of abnormal returns at the country level. To the extent these results are generalizable, they suggest investors should concern themselves with the covariance structure of returns across countries and not attempt to pick "winners." Similar to Case, Goetzman, and Rouwenhorst (1999), we find evidence of a strong world-wide factor in international real estate returns. However, even after controlling for the effects of world-wide systematic risk, an orthogonalized country-specific risk factor is highly significant in the vast majority of the ex post return regressions. This suggests that real estate securities may provide international diversification opportunities. This conclusion is further supported by our analysis of firm level return data. 


\section{References}

Asabere, P., R. Kleiman, and C. McGowan, 1991, “The Risk-Return Attributes of International Real Estate Equities,” Journal of Real Estate Research 6, 143-152.

Barkham, R. and D. Geltner, 1995, “Price Discovery in American and British Property Markets,” Real Estate Economics 23, 21-44.

Case, B., W. Goetzman, and K.G. Rouwenhorst, 1999, Global Real Estate Markets-Cycles and Fundamentals,” mimeo, Yale School of Management.

Chan, K.C., P.H. Hendershott, and A.B. Sanders, 1990, "Risk and Return on Real Estate: Evidence From Equity REITs,” AREUEA Journal 18(4), 431-452.

Chen, N., R. Roll and S. Ross, 1986, “Economic Forces and the Stock Market,” Journal of Business 59, pp. 383-403.

Corgel, J.B., A.J. Jaffe, and R.T. Lie, 1992, “Modelin the Economics of Leasing Provisions: Some Cross-Cultural Comparisons of European Contrast, Mimeo, Cornell University.

Eichholtz, P.M.A. and D.J. Hartzell, 1996, "Property Shares, Appraisals and the Stock Market: An International Perspective, 1996, Journal of Real Estate Finance and Economics 12, 163-178.

Eichholtz, P.M.A. and K.G. Koedijk, 1996, “The Global Real Estate Securities Market,” Real Estate Finance 13(1), 76-82.

Eichholtz, P.M.A., R. Huisman, K. Koedijk, and L. Schuin, 1998, “Continental Factors in International Real Estate Returns, Real Estate Economics 26(3), 493-509.

Fama, G. and K.R. French (1993), “Common Risk Factors in the Returns on Stocks and Bonds,” Journal of Financial Economics 33, 23-49.

Ferson, W. and C. Harvey, 1991, “The Variation of Economic Risk Premiums,” Journal of Political Economy 99, 385-415.

Geurts, T.G. and A.J. Jaffe, 1996, "Risk and Real Estate Investment: An International Perspective,” The Journal of Real Estate Research 11(2), 117-130.

Gilerberto, S.M. and A. Mengden, 1996, “REITs and Real Estate: Two Markets Reexamined,” Real Estate Finance 13(1), 56-60.

Glascock, J., 1991, “”Market Conditions, Risk, and Real Estate Portfolio Returns: Some Empirical Evidence,” Journal of Real Estate Finance and Economics, 4(4), 367-373.

Glascock, J. and W. T. Hughes, 1995, “ NAREIT Identified Exchange Listed REITs and Their Performance Characteristics,” Journal of Real Estate Literature, 3, 68-83. 
Goetzman, W. and S. Wachter, 1996, “The Global real Estate Crash: Evidence from an International Database,” mimeo, Yale School of Management.

Gyourko, J. and D. B. Keim, 1992, ” What Does the Stock Market Tell Us About Real Estate Returns,” Journal of the American Real Estate and Urban Economics Association, 20, 457-485.

Hartzell, D. J. and A. E. Mengden, 1987, Another Look at Equity Real Estate Investment Trust Returns, New York, Salomon Brothers, Inc.

Karolyi, G.A. and A.B. Sanders, 1999, “The Variation in Economic Risk Premiums in Real Estate Returns,

Kuhle, J. L, C. H. Walther, and C. H. Wurtzeback, 1987, “The Financial Performance of Real Estate Investment Trusts,” The Journal of Real Estate Research, 1(1), 67-75.

Ling, D. C. and A. Naranjo, 1996, "Economic Risk Factors and Commercial Real Estate Returns,” Journal of Real Estate Finance and Economics, 14, 283-307.

Ling, D. C. and A. Naranjo, 1999, “The Integration of Commercial Real Estate Markets and Stock Markets,” Real Estate Economics, 27(3), 483-516.

Ling, D.C., A. Naranjo, and M. Ryngaert, 2000, “The Predictability of Equity REIT Returns,” Journal of Real Estate Finance and Economics, forthcoming.

Liu, C.H., D.J. Hartzell, and M.E. Hoesli, 1997, “International Evidence on Real Estate Securities as an Inflation Hedge,” Real Estate Economics, 25(2), 193-222.

Liu, C.H. and J. Mei, 1996, “The Predictability of International Real Estate Markets, Exchange Risk, and Diversification Consequences, Real Estate Economics 26, 3-39.

Lizieri, C., S. Satchell, E. Worzala, and R. Dacco, 1998, "Real Interest Regimes and Real Estate Performance: A Comparison of U.K. and U.S. Markets,” Journal of Real Estate Research 16(3), 339-355.

McIntosh, W., Y. Liang, and D. L. Tompkins, 1991, “An Examination of the Small Firm Effect Within the REIT Industry,” The Journal of Real Estate Research, 6(1), 9-17.

Pagan, A., 1984, "Econometric Issues in the Analysis of Regressions with Generated Regressors," International Economic Review 25: 221-247. 


\section{Table 1}

\section{Summary Statistics for Commercial Real Estate Returns across Countries: Annualized Monthly \% Returns in U.S. Dollars: 1984-1999}

\begin{tabular}{|c|c|c|c|c|c|c|c|c|}
\hline & $\begin{array}{c}\text { Mean } \\
\text { Return }\end{array}$ & $\begin{array}{l}\text { Std. } \\
\text { Dev. }\end{array}$ & $\begin{array}{c}\text { Treynor } \\
\text { Ratio }\end{array}$ & $\begin{array}{c}\text { Treynor } \\
\text { Ratio } \\
\text { Rank }\end{array}$ & $\begin{array}{c}\text { Monthly } \\
\text { Obs. }\end{array}$ & $\begin{array}{l}\text { Ave. \# of } \\
\text { Firms in } \\
\text { Index }\end{array}$ & $\begin{array}{c}\text { Ave. Mkt. } \\
\text { Value } \\
\text { (mil. U.S. \$) }\end{array}$ & $\begin{array}{c}\text { Market } \\
\text { Value } \\
\text { Rank }\end{array}$ \\
\hline Australia & 14.9 & 18.0 & 1.37 & 6 & 192 & 15 & 6,066 & 8 \\
\hline Belgium & 7.5 & 17.6 & 0.63 & 12 & 156 & 2 & 442 & 16 \\
\hline Canada & -7.9 & 27.0 & -1.31 & 19 & 192 & 6 & 2,942 & 11 \\
\hline France & 11.4 & 17.0 & 0.89 & 8 & 192 & 35 & 12,768 & 6 \\
\hline Germany & 8.0 & 12.1 & 1.55 & 2 & 192 & 14 & 18,807 & 5 \\
\hline Hong Kong & 28.8 & 41.6 & 1.50 & 4 & 192 & 22 & 28,773 & 3 \\
\hline Ireland & 20.4 & 36.8 & 2.00 & 1 & 175 & 1 & 144 & 19 \\
\hline Italy & 12.5 & 27.2 & 0.89 & 7 & 192 & 4 & 871 & 15 \\
\hline Japan & 15.5 & 39.7 & 0.51 & 15 & 192 & 17 & 34,393 & 1 \\
\hline Malaysia & 14.1 & 57.4 & 0.53 & 14 & 168 & 5 & 1,040 & 13 \\
\hline Netherlands & 7.2 & 13.1 & 0.34 & 17 & 192 & 7 & 6,089 & 7 \\
\hline New Zealand & 3.3 & 27.3 & -0.41 & 18 & 144 & 3 & 264 & 18 \\
\hline Norway & 18.9 & 33.2 & 1.51 & 3 & 192 & 2 & 330 & 17 \\
\hline Singapore & 22.3 & 45.1 & 0.83 & 9 & 192 & 5 & 5,570 & 9 \\
\hline Spain & 12.0 & 33.1 & 0.62 & 13 & 154 & 2 & 884 & 14 \\
\hline Sweden & 9.3 & 36.9 & 0.41 & 16 & 192 & 4 & 1,202 & 12 \\
\hline Switzerland & 9.3 & 13.8 & 1.41 & 5 & 192 & 16 & 4,656 & 10 \\
\hline United Kingdom & 12.5 & 22.8 & 0.71 & 11 & 192 & 41 & 19,817 & 4 \\
\hline United States & 10.9 & 15.1 & 0.73 & 10 & 192 & 71 & 33,515 & 2 \\
\hline Aggregated GPR & 11.4 & 17.2 & 0.51 & - & 192 & 277 & 181,773 & 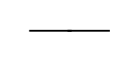 \\
\hline World Stock Portfolio & 15.9 & 14.4 & $\longrightarrow$ & & & . & & \\
\hline \multicolumn{9}{|l|}{ U. S. Benchmarks: } \\
\hline Large Cap Stocks & 17.7 & 14.8 & $\overline{-}$ & $\longrightarrow$ & & 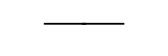 & & $\longrightarrow$ \\
\hline Small Cap Stocks & 13.1 & 17.8 & - & - & - & $\longrightarrow$ & - & - \\
\hline L-T Gov. Bonds & 11.2 & 9.7 & - & - & 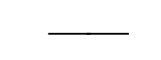 & - & - & 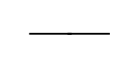 \\
\hline
\end{tabular}

The international real estate securities data are from the Global Real Estate Securities Database of Global Property Research (GPR). For the country real estate returns, we use the market-weighted GPR country indices which have been converted into U.S. dollars. The GPR database is consistent across countries with respect to the inclusion criteria of companies, the treatment of initial public offerings, and the distinction between property development and property investment companies. The GPR index is constructed to be representative of the movements in the worldwide real estate securities market. The country level and world capital market return indices are value-weighted equity indices (in U.S. dollar terms) constructed by Morgan Stanley. We obtain these data from Datastream. The U.S. benchmark data are from Ibbotson and Associates. The Treynor ratios are calculated using each country's $\beta$ eta with respect to the world portfolio (the $\beta$ eta estimates are shown in Table 4). 
Table 2

\section{Summary Statistics for Commercial Real Estate Returns across Countries: Annualized Monthly \% Returns in U.S. Dollars: 1984-1989}

\begin{tabular}{|c|c|c|c|c|c|c|c|c|}
\hline & $\begin{array}{c}\text { Mean } \\
\text { Return }\end{array}$ & $\begin{array}{l}\text { Std. } \\
\text { Dev. }\end{array}$ & $\begin{array}{c}\text { Treynor } \\
\text { Ratio }\end{array}$ & $\begin{array}{c}\text { Treynor } \\
\text { Ratio } \\
\text { Rank }\end{array}$ & $\begin{array}{c}\text { Monthly } \\
\text { Obs. }\end{array}$ & $\begin{array}{l}\text { Ave. \# of } \\
\text { Firms in } \\
\text { Index }\end{array}$ & $\begin{array}{c}\text { Ave. Mkt. } \\
\text { Value } \\
\text { (mil. U.S. \$) }\end{array}$ & $\begin{array}{c}\text { Market } \\
\text { Value } \\
\text { Rank }\end{array}$ \\
\hline Australia & 18.0 & 22.6 & 1.41 & 12 & 72 & 7 & 1,734 & 10 \\
\hline Belgium & 21.5 & 27.7 & 2.73 & 4 & 36 & 2 & 211 & 16 \\
\hline Canada & 18.1 & 23.5 & 1.13 & 15 & 72 & 5 & 2,877 & 8 \\
\hline France & 25.3 & 20.7 & 2.28 & 7 & 72 & 15 & 4,784 & 6 \\
\hline Germany & 15.3 & 13.8 & 0.05 & 18 & 72 & 10 & 5,561 & 5 \\
\hline Hong Kong & 38.4 & 39.6 & 2.21 & 8 & 72 & 17 & 7,934 & 4 \\
\hline Ireland & 26.1 & 43.9 & 1.92 & 9 & 55 & 1 & 24 & 20 \\
\hline Italy & 28.0 & 28.7 & 2.72 & 5 & 72 & 3 & 412 & 14 \\
\hline Japan & 48.5 & 47.8 & 2.35 & 6 & 72 & 10 & 31,640 & 1 \\
\hline Malaysia & 24.0 & 56.5 & 1.39 & 13 & 48 & 4 & 390 & 15 \\
\hline Netherlands & 17.3 & 12.4 & 2.84 & 3 & 72 & 5 & 2,836 & 9 \\
\hline New Zealand & 18.9 & 39.9 & -48.38 & 19 & 24 & 2 & 79 & 18 \\
\hline Norway & 33.8 & 34.0 & 4.17 & 2 & 72 & 1 & 136 & 17 \\
\hline Singapore & 28.6 & 46.0 & 1.34 & 14 & 72 & 3 & 1,009 & 11 \\
\hline Spain & 33.0 & 44.7 & 1.66 & 10 & 34 & 1 & 483 & 13 \\
\hline Sweden & 32.2 & 25.3 & 5.67 & 1 & 72 & 2 & 662 & 12 \\
\hline Switzerland & 13.3 & 15.9 & 1.61 & 11 & 72 & 14 & 3,548 & 7 \\
\hline United Kingdom & 21.0 & 26.9 & 1.12 & 16 & 72 & 36 & 11,566 & 2 \\
\hline United States & 15.7 & 15.5 & 1.00 & 17 & 72 & 38 & 9,316 & 3 \\
\hline Aggregate GPR & 26.4 & 19.5 & 1.66 & - & 72 & 171 & 84,660 & 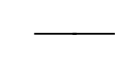 \\
\hline World Stock Portfolio & 22.5 & 15.2 & - & 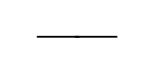 & 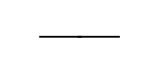 & - & - & 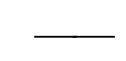 \\
\hline \multicolumn{9}{|l|}{ U. S. Benchmarks: } \\
\hline Large Cap Stocks & 17.2 & 15.6 & $\longrightarrow$ & $\longrightarrow$ & - & - & - & - \\
\hline Small Cap Stocks & 8.9 & 18.4 & - & - & - & - & - & - \\
\hline L-T Gov. Bonds & 15.2 & 11.9 & - & - & - & - & - & - \\
\hline
\end{tabular}

The international real estate securities data are from the Global Real Estate Securities Database of Global Property Research (GPR). For the country real estate returns, we use the market-weighted GPR country indices which have been converted into U.S. dollars. The GPR database is consistent across countries with respect to the inclusion criteria of companies, the treatment of initial public offerings, and the distinction between property development and property investment companies. The GPR index is constructed to be representative of the movements in the worldwide real estate securities market. The country level and world capital market return indices are value-weighted equity indices (in U.S. dollar terms) constructed by Morgan Stanley. We obtain these data from Datastream. The U.S. benchmark data are from Ibbotson and Associates. The Treynor ratios are calculated using each country's $\beta$ eta with respect to the world portfolio (the $\beta$ eta estimates are shown in Table 4). 


\section{Table 3}

\section{Summary Statistics for Commercial Real Estate Returns across Countries: Annualized Monthly \% Returns in U.S. Dollars: 1990-1999}

\begin{tabular}{|c|c|c|c|c|c|c|c|c|}
\hline & $\begin{array}{c}\text { Mean } \\
\text { Return }\end{array}$ & $\begin{array}{l}\text { Std. } \\
\text { Dev. }\end{array}$ & $\begin{array}{c}\text { Treynor } \\
\text { Ratio }\end{array}$ & $\begin{array}{c}\text { Treynor } \\
\text { Ratio } \\
\text { Rank }\end{array}$ & $\begin{array}{c}\text { Monthly } \\
\text { Obs. }\end{array}$ & $\begin{array}{l}\text { Ave. \# of } \\
\text { Firms in } \\
\text { Index }\end{array}$ & $\begin{array}{c}\text { Ave. Mkt. } \\
\text { Value } \\
\text { (mil.U.S. \$) }\end{array}$ & $\begin{array}{c}\text { Market } \\
\text { Value } \\
\text { Rank } \\
\end{array}$ \\
\hline Argentina & 19.6 & 43.4 & 0.69 & 6 & 77 & 1 & 396 & 22 \\
\hline Australia & 13.0 & 14.6 & 1.32 & 2 & 120 & 20 & 8,666 & 7 \\
\hline Austria & 1.8 & 13.0 & -13.35 & 28 & 120 & 4 & 604 & 18 \\
\hline Belgium & 3.5 & 13.1 & -0.59 & 20 & 120 & 2 & 511 & 20 \\
\hline Canada & -23.4 & 28.1 & 0.01 & 15 & 120 & 7 & 2,981 & 12 \\
\hline Denmark & 1.9 & 17.0 & -1.30 & 25 & 61 & 1 & 136 & 28 \\
\hline France & 3.0 & 13.8 & -0.35 & 17 & 120 & 47 & 17,559 & 6 \\
\hline Germany & 3.7 & 10.8 & -1.64 & 27 & 120 & 16 & 26,755 & 4 \\
\hline Hong Kong & 23.1 & 42.8 & 1.12 & 4 & 120 & 24 & 41,276 & 2 \\
\hline Indonesia & -1.9 & 71.0 & -0.64 & 21 & 117 & 3 & 386 & 23 \\
\hline Ireland & 17.8 & 33.3 & 2.15 & 1 & 120 & 1 & 199 & 26 \\
\hline Italy & 3.1 & 26.0 & -0.23 & 16 & 120 & 5 & 1,147 & 15 \\
\hline Japan & -4.3 & 32.8 & -0.46 & 19 & 120 & 21 & 36,045 & 3 \\
\hline Malaysia & 10.1 & 57.9 & 0.27 & 12 & 120 & 5 & 1,300 & 14 \\
\hline Mexico & -0.4 & 69.4 & -0.40 & 18 & 75 & 2 & 557 & 19 \\
\hline Netherlands & 1.1 & 13.2 & -0.84 & 23 & 120 & 9 & 8,041 & 9 \\
\hline New Zealand & 0.2 & 24.1 & -0.87 & 24 & 120 & 3 & 301 & 25 \\
\hline Norway & 10.0 & 32.6 & 0.51 & 9 & 120 & 2 & 446 & 21 \\
\hline Philippines & 11.6 & 46.5 & 0.44 & 10 & 99 & 2 & 4,033 & 11 \\
\hline Portugal & -7.7 & 32.2 & 0.00 & 26 & 120 & 2 & 177 & 27 \\
\hline Singapore & 18.5 & 44.7 & 0.60 & 7 & 120 & 6 & 8,307 & 8 \\
\hline South Africa & 16.0 & 31.7 & 0.79 & 5 & 31 & 5 & 369 & 24 \\
\hline Spain & 6.0 & 29.1 & 0.14 & 14 & 120 & 2 & 998 & 16 \\
\hline Sweden & -4.5 & 41.9 & -0.82 & 22 & 120 & 5 & 1,525 & 13 \\
\hline Switzerland & 6.9 & 12.4 & 1.27 & 3 & 120 & 17 & 5,320 & 10 \\
\hline Thailand & 16.6 & 165.2 & 0.25 & 13 & 105 & 1 & 675 & 17 \\
\hline United Kingdom & 7.4 & 19.9 & 0.33 & 11 & 120 & 44 & 24,767 & 5 \\
\hline United States & 7.9 & 14.9 & 0.52 & 8 & 120 & 90 & 48,035 & 1 \\
\hline Aggregate GPR & 2.4 & 15.2 & -0.24 & & 120 & 340 & 240,040 & 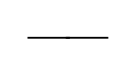 \\
\hline World Stock Portfolio & 11.8 & 13.8 & - & 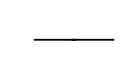 & 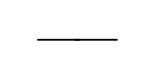 & - & 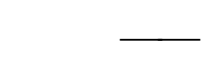 & - \\
\hline \multicolumn{9}{|l|}{ U. S. Benchmarks: } \\
\hline Large Cap Stocks & 18.0 & 13.3 & - & 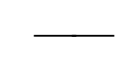 & 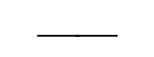 & - & 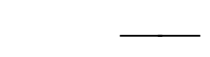 & 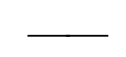 \\
\hline Small Cap Stocks & 15.7 & 17.4 & 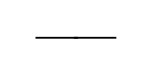 & - & & $\longrightarrow$ & 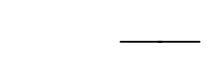 & - \\
\hline L-T Gov. Bonds & 8.8 & 8.2 & - & - & ـ & - & 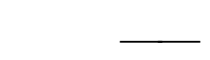 & - \\
\hline
\end{tabular}




\section{Table 3 continued}

The international real estate securities data are from the Global Real Estate Securities Database of Global Property Research (GPR). For the country real estate returns, we use the market-weighted GPR country indices which have been converted into U.S. dollars. The GPR database is consistent across countries with respect to the inclusion criteria of companies, the treatment of initial public offerings, and the distinction between property development and property investment companies. The GPR index is constructed to be representative of the movements in the worldwide real estate securities market. The country level and world capital market return indices are value-weighted equity indices (in U.S. dollar terms) constructed by Morgan Stanley. We obtain these data from Datastream. The U.S. benchmark data are from Ibbotson and Associates. The Treynor ratios are calculated using each country's $\beta$ eta with respect to the world portfolio (the $\beta$ eta estimates are shown in Table 4). 
Table 4

Single-Factor Performance of Commercial Real Estate Returns Monthly \% Excess Returns in U.S. Dollars

\begin{tabular}{|c|c|c|c|c|c|c|c|c|c|}
\hline & \multicolumn{3}{|c|}{$1984-1999$} & \multicolumn{3}{|c|}{1984 - 1989} & \multicolumn{3}{|c|}{$1990-1999$} \\
\hline & $\alpha_{i}$ & $\beta_{\mathrm{iW}}$ & Adj. $\mathrm{R}^{2}$ & $\alpha_{i}$ & $\beta_{\mathrm{iW}}$ & Adj. $\mathrm{R}^{2}$ & $\alpha_{i}$ & $\beta_{\mathrm{iW}}$ & Adj. $R^{2}$ \\
\hline Argentina & - & - & - & - & - & - & $\begin{array}{c}-0.399 \\
(-0.310)\end{array}$ & $\begin{array}{c}1.788 \\
(5.165)^{*}\end{array}$ & 0.255 \\
\hline Australia & $\begin{array}{c}0.281 \\
(0.816)\end{array}$ & $\begin{array}{c}0.562 \\
(6.944)^{*}\end{array}$ & 0.199 & $\begin{array}{c}0.061 \\
(0.084)\end{array}$ & $\begin{array}{c}0.643 \\
(4.013) *\end{array}$ & 0.175 & $\begin{array}{c}0.381 \\
(1.107)\end{array}$ & $\begin{array}{c}0.507 \\
(5.971)^{*}\end{array}$ & 0.227 \\
\hline Austria & - & - & - & - & - & - & $\begin{array}{c}-0.250 \\
(-0.715)\end{array}$ & $\begin{array}{c}0.019 \\
(0.217)\end{array}$ & -0.008 \\
\hline Belgium & $\begin{array}{c}-0.012 \\
(-0.030)\end{array}$ & $\begin{array}{c}0.300 \\
(3.208)^{*}\end{array}$ & 0.057 & $\begin{array}{c}0.769 \\
(0.582)\end{array}$ & $\begin{array}{c}0.458 \\
(1.728)^{*}\end{array}$ & 0.054 & $\begin{array}{c}-0.254 \\
(-0.740)\end{array}$ & $\begin{array}{c}0.221 \\
(2.613)^{*}\end{array}$ & 0.047 \\
\hline Canada & $\begin{array}{c}-1.890 \\
(-3.691)^{*}\end{array}$ & $\begin{array}{c}0.862 \\
(7.156) *\end{array}$ & 0.209 & $\begin{array}{c}-0.160 \\
(-0.223)\end{array}$ & $\begin{array}{c}0.817 \\
(5.219)^{*}\end{array}$ & 0.270 & $\begin{array}{c}-2.893 \\
(-4.226)^{*}\end{array}$ & $\begin{array}{c}0.847 \\
(5.008)^{*}\end{array}$ & 0.169 \\
\hline Denmark & - & - & - & - & - & - & $\begin{array}{c}-0.451 \\
(-0.681)\end{array}$ & $\begin{array}{c}0.201 \\
(1.137)\end{array}$ & 0.005 \\
\hline France & $\begin{array}{c}0.026 \\
(0.082)\end{array}$ & $\begin{array}{c}0.541 \\
(7.163)^{*}\end{array}$ & 0.209 & $\begin{array}{c}0.643 \\
(0.997)\end{array}$ & $\begin{array}{c}0.667 \\
(4.727)^{*}\end{array}$ & 0.231 & $\begin{array}{c}-0.383 \\
(-1.144)\end{array}$ & $\begin{array}{c}0.428 \\
(5.166)^{*}\end{array}$ & 0.179 \\
\hline Germany & $\begin{array}{c}0.091 \\
(0.355)\end{array}$ & $\begin{array}{c}0.129 \\
(2.154)^{*}\end{array}$ & 0.019 & $\begin{array}{c}0.414 \\
(0.859)\end{array}$ & $\begin{array}{c}0.207 \\
(1.965)^{*}\end{array}$ & 0.039 & $\begin{array}{c}-0.128 \\
(-0.442)\end{array}$ & $\begin{array}{c}0.061 \\
(0.853)\end{array}$ & -0.002 \\
\hline Hong Kong & $\begin{array}{c}0.789 \\
(0.991)\end{array}$ & $\begin{array}{c}1.283 \\
(6.850)^{*}\end{array}$ & 0.195 & $\begin{array}{c}1.055 \\
(0.836)\end{array}$ & $\begin{array}{c}1.181 \\
(4.280)^{*}\end{array}$ & 0.196 & $\begin{array}{c}0.669 \\
(0.647)\end{array}$ & $\begin{array}{c}1.353 \\
(5.293)^{*}\end{array}$ & 0.186 \\
\hline Indonesia & - & - & - & - & - & $\longrightarrow$ & $\begin{array}{c}-1.410 \\
(-0.738)\end{array}$ & $\begin{array}{c}0.866 \\
(1.810)^{*}\end{array}$ & 0.019 \\
\hline Ireland & $\begin{array}{c}0.720 \\
(0.896)\end{array}$ & $\begin{array}{c}0.630 \\
(3.366)^{*}\end{array}$ & 0.056 & $\begin{array}{c}0.299 \\
(0.172)\end{array}$ & $\begin{array}{c}0.851 \\
(2.333)^{*}\end{array}$ & 0.076 & $\begin{array}{c}0.826 \\
(0.941)\end{array}$ & $\begin{array}{c}0.503 \\
(2.319)^{*}\end{array}$ & 0.036 \\
\hline Italy & $\begin{array}{c}0.037 \\
(0.067)\end{array}$ & $\begin{array}{c}0.639 \\
(4.982)^{*}\end{array}$ & 0.111 & $\begin{array}{c}0.898 \\
(0.933)\end{array}$ & $\begin{array}{c}0.643 \\
(3.054)^{*}\end{array}$ & 0.105 & $\begin{array}{c}-0.472 \\
(-0.716)\end{array}$ & $\begin{array}{c}0.612 \\
(3.753)^{*}\end{array}$ & 0.100 \\
\hline Japan & $\begin{array}{c}-0.474 \\
(-0.689)\end{array}$ & $\begin{array}{c}1.601 \\
(9.901)^{*}\end{array}$ & 0.338 & $\begin{array}{c}1.514 \\
(1.001)\end{array}$ & $\begin{array}{c}1.470 \\
(4.443)^{*}\end{array}$ & 0.209 & $\begin{array}{c}-1.597 \\
(-2.538)^{*}\end{array}$ & $\begin{array}{c}1.644 \\
(10.577)^{*}\end{array}$ & 0.484 \\
\hline
\end{tabular}


Table 4 continued

\begin{tabular}{|c|c|c|c|c|c|c|c|c|c|}
\hline & \multicolumn{3}{|c|}{$1984-1999$} & \multicolumn{3}{|c|}{1984 - 1989} & \multicolumn{3}{|c|}{$1990-1999$} \\
\hline & $\alpha_{i}$ & $\beta_{\mathrm{iW}}$ & Adj. $R^{2}$ & $\alpha_{i}$ & $\beta_{\mathrm{iW}}$ & Adj. $R^{2}$ & $\alpha_{i}$ & $\beta_{\mathrm{iW}}$ & Adj. $\mathrm{R}^{2}$ \\
\hline Malaysia & $\begin{array}{c}-0.470 \\
(-0.384)\end{array}$ & $\begin{array}{c}1.409 \\
(4.982)^{*}\end{array}$ & 0.126 & $\begin{array}{c}-0.058 \\
(-0.025)\end{array}$ & $\begin{array}{c}1.061 \\
(2.228)^{*}\end{array}$ & 0.078 & $\begin{array}{c}-0.546 \\
(-0.379)\end{array}$ & $\begin{array}{c}1.608 \\
(4.516)^{*}\end{array}$ & 0.141 \\
\hline Mexico & - & - & $\longrightarrow$ & - & - & - & $\begin{array}{c}-1.212 \\
(-0.509)\end{array}$ & $\begin{array}{c}0.982 \\
(1.341)\end{array}$ & 0.011 \\
\hline Netherlands & $\begin{array}{c}-0.192 \\
(-0.747)\end{array}$ & $\begin{array}{c}0.348 \\
(5.759)^{*}\end{array}$ & 0.145 & $\begin{array}{c}0.456 \\
(1.097)\end{array}$ & $\begin{array}{c}0.299 \\
(3.296)^{*}\end{array}$ & 0.122 & $\begin{array}{c}-0.556 \\
(-1.704)^{*}\end{array}$ & $\begin{array}{c}0.367 \\
(4.555)^{*}\end{array}$ & 0.143 \\
\hline New Zealand & $\begin{array}{c}-0.439 \\
(-0.665)\end{array}$ & $\begin{array}{c}0.389 \\
(2.357)^{*}\end{array}$ & 0.031 & $\begin{array}{c}1.006 \\
(0.402)\end{array}$ & $\begin{array}{c}-0.020 \\
(-0.030)\end{array}$ & -0.045 & $\begin{array}{c}-0.679 \\
(-1.080)\end{array}$ & $\begin{array}{c}0.449 \\
(2.890)^{*}\end{array}$ & 0.059 \\
\hline Norway & $\begin{array}{c}0.475 \\
(0.705)\end{array}$ & $\begin{array}{c}0.729 \\
(4.600)^{*}\end{array}$ & 0.096 & $\begin{array}{c}1.523 \\
(1.292)\end{array}$ & $\begin{array}{c}0.535 \\
(2.074)^{*}\end{array}$ & 0.044 & $\begin{array}{c}-0.071 \\
(-0.087)\end{array}$ & $\begin{array}{c}0.847 \\
(4.183)^{*}\end{array}$ & 0.123 \\
\hline Philippines & - & - & - & - & - & - & $\begin{array}{c}-0.668 \\
(-0.510)\end{array}$ & $\begin{array}{c}1.375 \\
(3.781)^{*}\end{array}$ & 0.121 \\
\hline Portugal & - & - & - & - & - & - & $\begin{array}{c}-1.447 \\
(-1.752)^{*}\end{array}$ & $\begin{array}{c}0.720 \\
(3.519)^{*}\end{array}$ & 0.088 \\
\hline Singapore & $\begin{array}{c}-0.038 \\
(-0.047)\end{array}$ & $\begin{array}{c}1.664 \\
(8.631)^{*}\end{array}$ & 0.279 & $\begin{array}{c}0.025 \\
(0.017)\end{array}$ & $\begin{array}{c}1.345 \\
(4.156)^{*}\end{array}$ & 0.186 & $\begin{array}{c}0.041 \\
(0.042)\end{array}$ & $\begin{array}{c}1.904 \\
(7.924)^{*}\end{array}$ & 0.344 \\
\hline South Africa & - & - & - & - & - & - & $\begin{array}{c}-0.638 \\
(-0.447)\end{array}$ & $\begin{array}{c}1.173 \\
(3.802)^{*}\end{array}$ & 0.317 \\
\hline Spain & $\begin{array}{c}0.092 \\
(0.129)\end{array}$ & $\begin{array}{c}0.905 \\
(5.298)^{*}\end{array}$ & 0.151 & $\begin{array}{c}1.275 \\
(0.642)\end{array}$ & $\begin{array}{c}1.325 \\
(3.154)^{*}\end{array}$ & 0.213 & $\begin{array}{c}-0.234 \\
(-0.322)\end{array}$ & $\begin{array}{c}0.738 \\
(4.109)^{*}\end{array}$ & 0.119 \\
\hline Sweden & $\begin{array}{c}-0.345 \\
(-0.455)\end{array}$ & $\begin{array}{c}0.729 \\
(4.094)^{*}\end{array}$ & 0.077 & $\begin{array}{c}1.608 \\
(1.821)^{*}\end{array}$ & $\begin{array}{c}0.370 \\
(1.916)^{*}\end{array}$ & 0.036 & $\begin{array}{c}-1.364 \\
(-1.271)\end{array}$ & $\begin{array}{c}0.946 \\
(3.565)^{*}\end{array}$ & 0.090 \\
\hline Switzerland & $\begin{array}{c}0.129 \\
(0.448)\end{array}$ & $\begin{array}{c}0.220 \\
(3.243)^{*}\end{array}$ & 0.048 & $\begin{array}{c}0.096 \\
(0.176)\end{array}$ & $\begin{array}{c}0.323 \\
(2.713)^{*}\end{array}$ & 0.082 & $\begin{array}{c}0.111 \\
(0.337)\end{array}$ & $\begin{array}{c}0.142 \\
(1.747)^{*}\end{array}$ & 0.017 \\
\hline Thailand & - & - & ـ & - & - & - & $\begin{array}{c}-1.987 \\
(-0.430)\end{array}$ & $\begin{array}{c}3.993 \\
(3.098)^{*}\end{array}$ & 0.077 \\
\hline United Kingdom & $\begin{array}{c}-0.105 \\
(-0.250)\end{array}$ & $\begin{array}{c}0.805 \\
(8.128)^{*}\end{array}$ & 0.255 & $\begin{array}{c}-0.198 \\
(-0.252)\end{array}$ & $\begin{array}{c}1.034 \\
(6.016)^{*}\end{array}$ & 0.331 & $\begin{array}{c}-0.134 \\
(-0.278)\end{array}$ & $\begin{array}{c}0.635 \\
(5.331)^{*}\end{array}$ & 0.189 \\
\hline United States & $\begin{array}{c}-0.075 \\
(-0.281)\end{array}$ & $\begin{array}{c}0.585 \\
(9.260)^{*}\end{array}$ & 0.308 & $\begin{array}{c}-0.214 \\
(-0.538)\end{array}$ & $\begin{array}{c}0.709 \\
(8.141)^{*}\end{array}$ & 0.479 & $\begin{array}{c}-0.039 \\
(-0.109)\end{array}$ & $\begin{array}{c}0.496 \\
(5.624)^{*}\end{array}$ & 0.206 \\
\hline Aggregate & $\begin{array}{c}-0.321 \\
(-1.391)\end{array}$ & $\begin{array}{c}0.933 \\
(17.192)^{*}\end{array}$ & 0.608 & $\begin{array}{c}0.336 \\
(0.729)\end{array}$ & $\begin{array}{c}0.968 \\
(9.605)^{*}\end{array}$ & 0.562 & $\begin{array}{c}-0.721 \\
(-2.976)^{*}\end{array}$ & $\begin{array}{c}0.887 \\
(14.828)^{*}\end{array}$ & 0.650 \\
\hline
\end{tabular}




\section{Table 4 continued}

t-statistics in parentheses: * denotes significance at the $10 \%$ level or below.

For each of the three sample periods and for each country, we estimate the following model:

$R_{i t}-R_{f t}=\alpha_{i}+\beta_{i w}\left[R_{w t}-R_{f t}\right]+e_{i t}$

where:

$R_{i t}=$ the return in U.S. dollars on country i's real estate total return index in time period $t$,

$R_{f t}=$ the U.S. T-bill rate in time period $t$,

$\alpha_{i}=$ a constant (Jensen's alpha),

$\beta_{i w}=$ the return sensitivity (exposure) of country $i$ 's real estate returns to returns on the world equity portfolio,

$R_{w t}=$ the total return in U.S. dollars on the world equity portfolio from Morgan Stanley in time period $t$,

$e_{i t}=$ an error term. 
Table 5

Multi-Index Performance of Commercial Real Estate Returns Monthly \% Excess Returns in U.S. Dollars

\begin{tabular}{|c|c|c|c|c|c|c|c|c|c|c|c|c|}
\hline & \multicolumn{4}{|c|}{1984 - 1999} & \multicolumn{4}{|c|}{1984 - 1989} & \multicolumn{4}{|c|}{$1990-1999$} \\
\hline & $\alpha_{i}$ & $\beta_{\mathrm{iW}}$ & $\beta_{\mathrm{iR}}$ & Adj. $\mathrm{R}^{2}$ & $\alpha_{i}$ & $\beta_{\mathrm{iW}}$ & $\beta_{\mathrm{iR}}$ & Adj. $\mathrm{R}^{2}$ & $\alpha_{\mathrm{i}}$ & $\beta_{\mathrm{iW}}$ & $\beta_{\mathrm{iR}}$ & Adj. $\mathrm{R}^{2}$ \\
\hline Argentina & - & - & - & - & - & 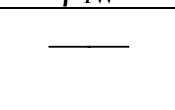 & - & - & $\begin{array}{c}-0.430 \\
(-0.422)\end{array}$ & $\begin{array}{c}1.782 \\
(6.501)^{*}\end{array}$ & $\begin{array}{c}0.850 \\
(6.717)^{*}\end{array}$ & 0.533 \\
\hline Australia & $\begin{array}{c}0.285 \\
(1.251)\end{array}$ & $\begin{array}{c}0.561 \\
(10.466)^{*}\end{array}$ & $\begin{array}{c}0.594 \\
(15.578)^{*}\end{array}$ & 0.649 & $\begin{array}{c}0.086 \\
(0.187)\end{array}$ & $\begin{array}{c}0.568 \\
(5.626)^{*}\end{array}$ & $\begin{array}{c}0.578 \\
(10.395)^{*}\end{array}$ & 0.674 & $\begin{array}{c}0.402 \\
(1.634)\end{array}$ & $\begin{array}{c}0.567 \\
(9.289)^{*}\end{array}$ & $\begin{array}{c}0.632 \\
(10.605)^{*}\end{array}$ & 0.604 \\
\hline Austria & - & 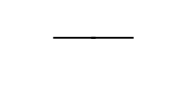 & - & - & - & - & - & 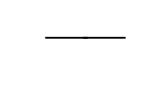 & $\begin{array}{c}-0.190 \\
(-0.548)\end{array}$ & $\begin{array}{c}0.018 \\
(0.207)\end{array}$ & $\begin{array}{c}0.110 \\
(2.001)^{*}\end{array}$ & 0.017 \\
\hline Belgium & $\begin{array}{c}-0.010 \\
(-0.026)\end{array}$ & $\begin{array}{c}0.301 \\
(3.347)^{*}\end{array}$ & $\begin{array}{c}0.385 \\
(3.765)^{*}\end{array}$ & 0.132 & $\begin{array}{c}0.724 \\
(0.543)\end{array}$ & $\begin{array}{c}0.407 \\
(1.473)\end{array}$ & $\begin{array}{c}0.205 \\
(0.709)\end{array}$ & 0.040 & $\begin{array}{c}-0.214 \\
(-0.684)\end{array}$ & $\begin{array}{c}0.274 \\
(3.510)^{*}\end{array}$ & $\begin{array}{c}0.456 \\
(4.897)^{*}\end{array}$ & 0.203 \\
\hline Canada & $\begin{array}{c}-1.893 \\
(-4.064)^{*}\end{array}$ & $\begin{array}{c}0.861 \\
(7.859)^{*}\end{array}$ & $\begin{array}{c}0.830 \\
(6.356)^{*}\end{array}$ & 0.345 & $\begin{array}{c}0.068 \\
(0.105)\end{array}$ & $\begin{array}{c}0.787 \\
(5.545)^{*}\end{array}$ & $\begin{array}{c}0.709 \\
(4.035)^{*}\end{array}$ & 0.401 & $\begin{array}{c}-3.064 \\
(-4.982)^{*}\end{array}$ & $\begin{array}{c}0.866 \\
(5.707)^{*}\end{array}$ & $\begin{array}{c}0.952 \\
(5.409) *\end{array}$ & 0.331 \\
\hline Denmark & - & - & - & ـ & - & - & - & ـ & $\begin{array}{c}-0.471 \\
(-0.762)\end{array}$ & $\begin{array}{c}0.207 \\
(1.257)\end{array}$ & $\begin{array}{c}0.482 \\
(3.118)^{*}\end{array}$ & 0.135 \\
\hline France & $\begin{array}{c}0.027 \\
(0.096)\end{array}$ & $\begin{array}{c}0.543 \\
(8.256)^{*}\end{array}$ & $\begin{array}{c}0.492 \\
(7.828)^{*}\end{array}$ & 0.401 & $\begin{array}{c}0.534 \\
(0.975)\end{array}$ & $\begin{array}{c}0.591 \\
(4.904)^{*}\end{array}$ & $\begin{array}{c}0.522 \\
(5.325)^{*}\end{array}$ & 0.447 & $\begin{array}{c}-.0308 \\
(-1.004)\end{array}$ & $\begin{array}{c}.0479 \\
(6.262)^{*}\end{array}$ & $\begin{array}{c}.0417 \\
(4.867)^{*}\end{array}$ & 0.312 \\
\hline Germany & $\begin{array}{c}0.089 \\
(0.364)\end{array}$ & $\begin{array}{c}0.130 \\
(2.258)^{*}\end{array}$ & $\begin{array}{c}0.201 \\
(4.161)^{*}\end{array}$ & 0.097 & $\begin{array}{c}0.359 \\
(0.798)\end{array}$ & $\begin{array}{c}0.204 \\
(2.078)^{*}\end{array}$ & $\begin{array}{c}0.239 \\
(3.410)^{*}\end{array}$ & 0.165 & $\begin{array}{c}-0.110 \\
(-0.383)\end{array}$ & $\begin{array}{c}0.064 \\
(0.910)\end{array}$ & $\begin{array}{c}0.142 \\
(2.056)^{*}\end{array}$ & 0.025 \\
\hline Hong Kong & $\begin{array}{c}0.799 \\
(2.743)^{*}\end{array}$ & $\begin{array}{c}1.283 \\
(18.724)^{*}\end{array}$ & $\begin{array}{c}1.296 \\
(34.992)^{*}\end{array}$ & 0.892 & $\begin{array}{c}1.219 \\
(2.944)^{*}\end{array}$ & $\begin{array}{c}1.224 \\
(13.510)^{*}\end{array}$ & $\begin{array}{c}1.201 \\
(24.099)^{*}\end{array}$ & 0.913 & $\begin{array}{c}0.559 \\
(1.435)\end{array}$ & $\begin{array}{c}1.311 \\
(13.612)^{*}\end{array}$ & $\begin{array}{c}1.360 \\
(26.615)^{*}\end{array}$ & 0.885 \\
\hline Indonesia & - & - & - & 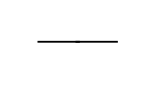 & - & - & - & 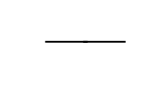 & $\begin{array}{c}-0.995 \\
(-0.817)\end{array}$ & $\begin{array}{c}0.709 \\
(2.324)^{*}\end{array}$ & $\begin{array}{c}1.110 \\
(12.939) *\end{array}$ & 0.601 \\
\hline Ireland & $\begin{array}{c}0.719 \\
(0.894)\end{array}$ & $\begin{array}{c}0.630 \\
(3.360)^{*}\end{array}$ & $\begin{array}{c}0.051 \\
(0.617)\end{array}$ & 0.053 & $\begin{array}{c}0.287 \\
(0.163)\end{array}$ & $\begin{array}{c}0.842 \\
(2.256)^{*}\end{array}$ & $\begin{array}{c}-0.015 \\
(-0.142)\end{array}$ & 0.059 & $\begin{array}{c}0.455 \\
(0.531)\end{array}$ & $\begin{array}{c}0.258 \\
(1.150)\end{array}$ & $\begin{array}{c}0.633 \\
(3.054)^{*}\end{array}$ & 0.100 \\
\hline Italy & $\begin{array}{c}0.026 \\
(0.062)\end{array}$ & $\begin{array}{c}0.641 \\
(6.593)^{*}\end{array}$ & $\begin{array}{c}0.736 \\
(11.872)^{*}\end{array}$ & 0.489 & $\begin{array}{c}0.409 \\
(0.562)\end{array}$ & $\begin{array}{c}0.620 \\
(3.910)^{*}\end{array}$ & $\begin{array}{c}0.774 \\
(7.402)^{*}\end{array}$ & 0.494 & $\begin{array}{c}-0.217 \\
(-0.428)\end{array}$ & $\begin{array}{c}0.644 \\
(5.137)^{*}\end{array}$ & $\begin{array}{c}0.707 \\
(9.056) *\end{array}$ & 0.468 \\
\hline Japan & $\begin{array}{c}-0.429 \\
(-0.844)\end{array}$ & $\begin{array}{c}1.600 \\
(13.406)^{*}\end{array}$ & $\begin{array}{c}1.302 \\
(12.613)^{*}\end{array}$ & 0.640 & $\begin{array}{c}-0.444 \\
(-0.378)\end{array}$ & $\begin{array}{c}1.791 \\
(7.052)^{*}\end{array}$ & $\begin{array}{c}1.747 \\
(7.313)^{*}\end{array}$ & 0.548 & $\begin{array}{c}-0.916 \\
(-2.174)^{*}\end{array}$ & $\begin{array}{c}1.530 \\
(14.759)^{*}\end{array}$ & $\begin{array}{c}1.050 \\
(12.214)^{*}\end{array}$ & 0.773 \\
\hline
\end{tabular}


Table 5 continued

\begin{tabular}{|c|c|c|c|c|c|c|c|c|c|c|c|c|}
\hline & \multicolumn{4}{|c|}{$1984-1999$} & \multicolumn{4}{|c|}{$1984-1989$} & \multicolumn{4}{|c|}{$1990-1999$} \\
\hline & $\alpha_{i}$ & $\beta_{\mathrm{iW}}$ & $\beta_{\mathrm{iR}}$ & Adj. $\mathrm{R}^{2}$ & $\alpha_{i}$ & $\beta_{\mathrm{iW}}$ & $\beta_{\mathrm{iR}}$ & Adj. $\mathrm{R}^{2}$ & $\alpha_{I}$ & $\beta_{\mathrm{iW}}$ & $\beta_{\mathrm{iR}}$ & Adj. $R^{2}$ \\
\hline Malaysia & $\begin{array}{c}-0.479 \\
(-0.448)\end{array}$ & $\begin{array}{c}1.408 \\
(5.700)^{*}\end{array}$ & $\begin{array}{c}0.611 \\
(7.231)^{*}\end{array}$ & 0.333 & $\begin{array}{c}-0.022 \\
(-0.009)\end{array}$ & $\begin{array}{c}1.163 \\
(2.364)^{*}\end{array}$ & $\begin{array}{c}0.119 \\
(0.862)\end{array}$ & 0.073 & $\begin{array}{c}-0.963 \\
(-1.026)\end{array}$ & $\begin{array}{c}0.979 \\
(4.130)^{*}\end{array}$ & $\begin{array}{c}1.199 \\
(12.650) *\end{array}$ & 0.636 \\
\hline Mexico & - & - & - & - & - & (2) & 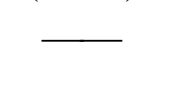 & . & $\begin{array}{l}-1.087 \\
(-0.490)\end{array}$ & $\begin{array}{c}0.998 \\
(1.436)\end{array}$ & $\begin{array}{c}0.790 \\
(3.670)^{*}\end{array}$ & 0.158 \\
\hline Netherlands & $\begin{array}{c}-0.191 \\
(-0.765)\end{array}$ & $\begin{array}{c}0.349 \\
(5.938)^{*}\end{array}$ & $\begin{array}{c}0.273 \\
(3.502)^{*}\end{array}$ & 0.193 & $\begin{array}{c}0.468 \\
(1.131)\end{array}$ & $\begin{array}{c}0.288 \\
(3.168)^{*}\end{array}$ & $\begin{array}{c}0.148 \\
(1.317)\end{array}$ & 0.131 & $\begin{array}{c}-0.560 \\
(-1.808) *\end{array}$ & $\begin{array}{c}0.392 \\
(5.098)^{*}\end{array}$ & $\begin{array}{c}0.396 \\
(3.706)^{*}\end{array}$ & 0.227 \\
\hline New Zealand & $\begin{array}{c}-0.944 \\
(-1.779)^{*}\end{array}$ & $\begin{array}{c}0.260 \\
(1.961)^{*}\end{array}$ & $\begin{array}{c}0.752 \\
(8.971)^{*}\end{array}$ & 0.380 & $\begin{array}{c}0.243 \\
(0.132)\end{array}$ & $\begin{array}{c}0.508 \\
(1.004)\end{array}$ & $\begin{array}{c}0.889 \\
(4.477)^{*}\end{array}$ & 0.440 & $\begin{array}{l}-1.182 \\
(-2.227) *\end{array}$ & $\begin{array}{c}0.241 \\
(1.813)^{*}\end{array}$ & $\begin{array}{c}0.698 \\
(7.167)^{*}\end{array}$ & 0.342 \\
\hline Norway & $\begin{array}{c}0.479 \\
(0.756)\end{array}$ & $\begin{array}{c}0.731 \\
(4.908)^{*}\end{array}$ & $\begin{array}{c}0.523 \\
(5.118)^{*}\end{array}$ & 0.202 & $\begin{array}{c}1.368 \\
(1.246)\end{array}$ & $\begin{array}{c}0.472 \\
(1.962)^{*}\end{array}$ & $\begin{array}{c}0.566 \\
(3.446)^{*}\end{array}$ & 0.173 & $\begin{array}{c}0.036 \\
(0.047)\end{array}$ & $\begin{array}{c}0.896 \\
(4.662)^{*}\end{array}$ & $\begin{array}{c}0.502 \\
(3.805)^{*}\end{array}$ & 0.213 \\
\hline Philippines & 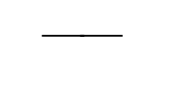 & - & thes & 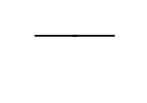 & - & - & - & 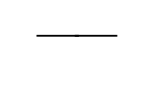 & $\begin{array}{c}-0.725 \\
(-0.615)\end{array}$ & $\begin{array}{c}1.355 \\
(4.132)^{*}\end{array}$ & $\begin{array}{c}0.593 \\
(4.808)^{*}\end{array}$ & 0.285 \\
\hline Portugal & 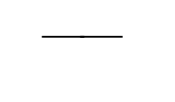 & 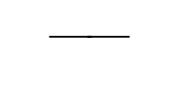 & . & . & - & - & - & 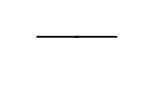 & $\begin{array}{c}-1.460 \\
(-1.825)^{*}\end{array}$ & $\begin{array}{c}0.715 \\
(3.620)^{*}\end{array}$ & $\begin{array}{c}0.438 \\
(2.965)^{*}\end{array}$ & 0.145 \\
\hline Singapore & $\begin{array}{c}0.024 \\
(0.057)\end{array}$ & $\begin{array}{c}1.652 \\
(16.919) *\end{array}$ & $\begin{array}{c}1.427 \\
(23.429) *\end{array}$ & 0.815 & $\begin{array}{c}0.477 \\
(0.668)\end{array}$ & $\begin{array}{c}1.649 \\
(10.476)^{*}\end{array}$ & $\begin{array}{c}1.415 \\
(15.230)^{*}\end{array}$ & 0.811 & $\begin{array}{c}-0.249 \\
(-0.483)\end{array}$ & $\begin{array}{c}1.636 \\
(12.752)^{*}\end{array}$ & $\begin{array}{c}1.446 \\
(17.333)^{*}\end{array}$ & 0.816 \\
\hline South Africa & - & - & - & - & - & - & - & 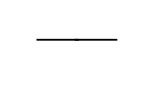 & $\begin{array}{c}-0.744 \\
(-0.607)\end{array}$ & $\begin{array}{c}1.137 \\
(4.297)^{*}\end{array}$ & $\begin{array}{c}0.488 \\
(3.337)^{*}\end{array}$ & 0.499 \\
\hline Spain & $\begin{array}{c}0.085 \\
(0.126)\end{array}$ & $\begin{array}{c}0.905 \\
(5.667)^{*}\end{array}$ & $\begin{array}{c}0.652 \\
(4.757) *\end{array}$ & 0.258 & $\begin{array}{c}1.263 \\
(0.628)\end{array}$ & $\begin{array}{c}1.374 \\
(3.100)^{*}\end{array}$ & $\begin{array}{c}0.157 \\
(0.399)\end{array}$ & 0.192 & $\begin{array}{c}-0.222 \\
(-0.361)\end{array}$ & $\begin{array}{c}0.629 \\
(4.126)^{*}\end{array}$ & $\begin{array}{c}0.897 \\
(6.937)^{*}\end{array}$ & 0.372 \\
\hline Sweden & $\begin{array}{c}-0.369 \\
(-0.522)\end{array}$ & $\begin{array}{c}0.727 \\
(4.374)^{*}\end{array}$ & $\begin{array}{c}0.733 \\
(5.335)^{*}\end{array}$ & 0.194 & $\begin{array}{c}1.559 \\
(1.837)^{*}\end{array}$ & $\begin{array}{c}0.450 \\
(2.390)^{*}\end{array}$ & $\begin{array}{c}0.397 \\
(2.613)^{*}\end{array}$ & 0.110 & $\begin{array}{c}-1.416 \\
(-1.434)\end{array}$ & $\begin{array}{c}0.798 \\
(3.245)^{*}\end{array}$ & $\begin{array}{c}0.969 \\
(4.717)^{*}\end{array}$ & 0.230 \\
\hline Switzerland & $\begin{array}{c}0.138 \\
(0.538)\end{array}$ & $\begin{array}{c}0.220 \\
(3.649) *\end{array}$ & $\begin{array}{c}0.451 \\
(7.190)^{*}\end{array}$ & 0.249 & $\begin{array}{c}0.233 \\
(0.465)\end{array}$ & $\begin{array}{c}0.326 \\
(2.982)^{*}\end{array}$ & $\begin{array}{c}0.401 \\
(3.755)^{*}\end{array}$ & 0.227 & $\begin{array}{c}0.023 \\
(0.080)\end{array}$ & $\begin{array}{c}0.134 \\
(1.932)^{*}\end{array}$ & $\begin{array}{c}0.506 \\
(6.621)^{*}\end{array}$ & 0.281 \\
\hline Thailand & - & - & - & 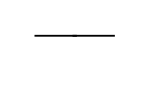 & - & - & - & 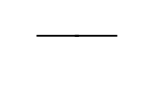 & $\begin{array}{c}-1.558 \\
(-0.393)\end{array}$ & $\begin{array}{c}3.841 \\
(3.481)^{*}\end{array}$ & $\begin{array}{c}2.047 \\
(6.181)^{*}\end{array}$ & 0.324 \\
\hline United Kingdom & $\begin{array}{c}-0.115 \\
(-0.370)\end{array}$ & $\begin{array}{c}0.808 \\
(11.083)^{*}\end{array}$ & $\begin{array}{c}1.081 \\
(12.686)^{*}\end{array}$ & 0.597 & $\begin{array}{c}0.118 \\
(0.227)\end{array}$ & $\begin{array}{c}0.827 \\
(7.125)^{*}\end{array}$ & $\begin{array}{c}1.091 \\
(9.491)^{*}\end{array}$ & 0.706 & $\begin{array}{c}-0.255 \\
(-0.653)\end{array}$ & $\begin{array}{c}0.783 \\
(7.954)^{*}\end{array}$ & $\begin{array}{c}1.058 \\
(7.854)^{*}\end{array}$ & 0.466 \\
\hline United States & $\begin{array}{c}-0.082 \\
(-0.343)\end{array}$ & $\begin{array}{c}0.586 \\
(10.375) *\end{array}$ & $\begin{array}{c}0.609 \\
(6.977)^{*}\end{array}$ & 0.448 & $\begin{array}{c}0.210 \\
(0.723)\end{array}$ & $\begin{array}{c}0.648 \\
(10.309) *\end{array}$ & $\begin{array}{c}0.738 \\
(8.191)^{*}\end{array}$ & 0.732 & $\begin{array}{c}-0.199 \\
(-0.577)\end{array}$ & $\begin{array}{c}0.519 \\
(6.144)^{*}\end{array}$ & $\begin{array}{c}0.490 \\
(3.483)^{*}\end{array}$ & 0.275 \\
\hline
\end{tabular}




\section{Table 5 continued}

t-statistics in parentheses: * denotes significance at the $10 \%$ level or below.

For each of the three sample periods and for each country, we use a two-step estimation procedure. In the first step, we regress excess country-wide stock returns (in excess of the risk free rate) on the excess returns earned on world equity portfolio. In particular, we estimate the following regression:

$R_{i t}^{s}-R_{f t}=\alpha_{i}^{s}+\beta_{i w}^{s}\left[R_{w t}-R_{f t}\right]+e_{i t}^{s}$,

where $R_{i t}^{s}$ is the total return on country i's stock index, $R_{f t}$ is the U.S. T-bill rate, and $R_{w t}$ is the total return on the world equity portfolio in time period $t$. The equity data are from Morgan Stanley. $e_{i t}^{s}$ are the unexplained residuals. These residuals represent the portion of each country's stock returns that are not explained by movements in the world wealth portfolio. In the second step, we include the orthogonalized country-specific risk factor (i.e., the orthogonalized residuals) as an explanatory variable in the real estate return regressions and estimate the following equation:

$R_{i t}-R_{f t}=\alpha_{i}+\beta_{i w}\left[R_{w t}-R_{f t}\right]+\beta_{i R} e_{i t}^{s}+u_{i t}$

$R_{i t}$ is the return on country i's real estate total return index in time period $t$, and $R_{f t}$ is the U.S. T-bill rate in time period $t$. $\beta_{i w}$ is the estimated return sensitivity of country i's GPR index to returns on the world wealth portfolio $\left(\mathrm{R}_{\mathrm{wt}}\right)$. $\beta_{i R}$ is the estimated sensitivity of country i's GPR index to returns on the orthoganalized country specific risk factor ( $\left.e^{s} i t\right)$. The estimated constants ( $\alpha_{i}$ - Jensen's alphas) from these two-factor models can be used as evidence of superior risk-adjusted return performance. 


\section{Table 6}

Summary Statistics on Average Firm Level Returns across Countries: Annualized Monthly \% Total Returns and Std. Deviations in U.S. Dollars: 1990-1999

\begin{tabular}{lcccrrrr}
\hline & & \multicolumn{5}{c}{ Average Returns } \\
\cline { 2 - 7 } & \# of Firms & High & Std. Dev. & Median & Std. Dev. & Low & Std. Dev. \\
\hline Australia & 3 & 5.6 & 11.3 & 4.0 & 25.4 & 3.2 & 11.2 \\
Austria & 10 & 33.6 & 25.5 & 12.4 & 16.2 & 6.3 & 17.1 \\
Canada & 3 & 8.5 & 37.8 & -11.3 & 28.1 & -26.1 & 55.5 \\
France & 29 & 25.2 & 45.3 & 7.4 & 21.8 & -24.0 & 39.8 \\
Germany & 14 & 5.3 & 13.9 & 3.8 & 10.4 & -11.1 & 36.4 \\
Hong Kong & 20 & 36.3 & 50.1 & 19.3 & 47.0 & -15.8 & 76.7 \\
Italy & 4 & 14.4 & 46.5 & 2.0 & 34.0 & 1.4 & 33.4 \\
Japan & 19 & 3.5 & 57.5 & -4.0 & 54.2 & -11.9 & 36.6 \\
Malaysia & 3 & 26.0 & 82.9 & 20.3 & 75.2 & 8.1 & 56.3 \\
Netherlands & 7 & 9.7 & 12.8 & 1.6 & 14.5 & -5.1 & 22.9 \\
Singapore & 4 & 27.2 & 48.9 & 13.9 & 43.9 & 8.1 & 45.4 \\
Switzerland & 15 & 9.4 & 13.9 & 8.1 & 14.2 & 4.4 & 31.5 \\
United Kingdom & 32 & 74.5 & 276.4 & 9.6 & 26.8 & -19.1 & 44.2 \\
United States & 39 & 33.6 & 49.2 & 12.2 & 21.4 & -6.3 & 28.9 \\
\hline
\end{tabular}

To be included in the company level sample, a total return for the firm must have been reported in at least 90 of the 120 months that comprise the 1990-1999 time period. The firm level international real estate securities data are from the Global Real Estate Securities Database of Global Property Research (GPR). The GPR database is consistent across countries with respect to the inclusion criteria of companies, the treatment of initial public offerings, and the distinction between property development and property investment companies. 


\section{Table 7}

\section{Firm Level Multi-Index Performance of Commercial Real Estate Returns: Monthly \% Excess Returns in U.S. Dollars: 1990-1999}

\begin{tabular}{|c|c|c|c|c|}
\hline & $\begin{array}{l}\text { \# of Firms } \\
\text { in Sample }\end{array}$ & $\begin{array}{c}\text { Number of Firms } \\
\text { With + Alphas }\end{array}$ & $\begin{array}{l}\text { Number of Firms } \\
\text { With - Alphas }\end{array}$ & $\begin{array}{l}\text { High-Low Range } \\
\text { Of Signif. Alphas }\end{array}$ \\
\hline Australia & 10 & 2 & 0 & 0.25 \\
\hline Austria & 3 & 0 & 0 & -- \\
\hline Canada & 3 & 0 & 2 & 1.25 \\
\hline France & 29 & 0 & 2 & 1.53 \\
\hline Germany & 14 & 0 & 0 & -- \\
\hline Hong Kong & 20 & 2 & 1 & 4.08 \\
\hline Italy & 4 & 0 & 0 & -- \\
\hline Japan & 20 & 0 & 17 & 1.41 \\
\hline Malaysia & 3 & 0 & 0 & -- \\
\hline Netherlands & 7 & 0 & 1 & -- \\
\hline Singapore & 4 & 0 & 0 & -- \\
\hline Switzerland & 15 & 0 & 0 & -- \\
\hline United Kingdom & 32 & 0 & 1 & -- \\
\hline United States & 38 & 5 & 0 & 1.38 \\
\hline Totals & 202 & 9 & 24 & \\
\hline
\end{tabular}

The number of positive and negatives alphas are based on the number of significant firm level alphas (at the 10\% level). The alphas are based on the two-factor model described below.

To be included in the company level sample, a total return for the firm must have been reported in at least 90 of the 120 months that comprise the 1990-1999 time period. The firm level international real estate securities data are from the Global Real Estate Securities Database of Global Property Research (GPR). The GPR database is consistent across countries with respect to the inclusion criteria of companies, the treatment of initial public offerings, and the distinction between property development and property investment companies.

For each firm in each country, we use a two-step estimation procedure. In the first step, we regress excess countrywide stock returns (in excess of the risk free rate) on the excess returns earned on world equity portfolio. In particular, we estimate the following regression:

$R_{i t}^{s}-R_{f t}=\alpha_{i}^{s}+\beta_{i w}^{s}\left[R_{w t}-R_{f t}\right]+e_{i t}^{s}$,

where $R_{i t}^{S}$ is the total return on country $i$ 's stock index, $R_{f t}$ is the U.S. T-bill rate, and $R_{w t}$ is the total return on the world equity portfolio in time period $t$. The equity return data are from Morgan Stanley. $e_{i t}^{s}$ are the unexplained residuals which represent the portion of each country's stock market returns that are not explained by movements in the world stock portfolio. In the second step, we include the orthogonalized country-specific risk factor (i.e., the orthogonalized residuals) as an explanatory variable in the following firm level real estate return regressions:

$R_{i t}-R_{f t}=\alpha_{i}+\beta_{i w}\left[R_{w t}-R_{f t}\right]+\beta_{i R} e_{i t}^{s}+u_{i t}$

$R_{i t}$ is the return on firm $i$ (in country $i$ ) in time period $t$, and $R_{f t}$ is the U.S. T-bill rate in time period $t$. $\beta_{\text {iw }}$ is the estimated return sensitivity of firm $i$ to returns on the world wealth portfolio $\left(\mathrm{R}_{w t}\right)$. $\beta_{i R}$ is the estimated return sensitivity of firm $i$ to returns on the orthoganalized country specific risk factor $\left(e^{s} i t\right)$. The estimated firm level constants ( $\alpha_{i}$ - Jensen's alphas) from these two-factor models can be used as evidence of superior risk-adjusted return performance. 